\title{
ESPAÇAMENTO ECONÔMICO DE DRENOS LATERAIS E A DINÂMICA DO LENÇOL FREÁTICO SOBRE O RENDIMENTO DA CULTURA DE MILHO(Zea mays, L.)
}

\author{
RAIMUNDO NONATO TÁVORA COSTA \\ Engenheiro Agrônomo
}

Orientador: Prof. Dr. DÉCIO EUGÊNIO CRUCIANI

Tese apresentada à Escola Superior de Agricultura "Luiz de Queiroz", da Universidade de São Paulo, para obtenção do título de Doutor em Agronomia, Área de Concentração: Irrigação e Drenagem.

P I R A C I C A B A

Estado de São Paulo - Brasil

Novembro de 1994 
Fictra catalografica preparada pela Seçăo de Livras da Divisấ de Bitlioteca e Documentaçăo - FCLR/USF

Costa, Faimundo Nonato Távora

cas7e Espaçamento econamico de drenos laterais e a di namica do lençol freatico sotre o rendimento da cultura de milto (Zea mays L.). Firacicaba, 1974. äp. il.

TESE - ESALR

Bibliografia.

1. Ereno - Espaçamento 2. Lençol frético 3. Mi 1ho - Estresse 4. Miltso rendimento I. Escola Superior de Agricultura Luiz de Rueiraz, Firacicata.

$$
\operatorname{SDD} 631.6
$$
633.15 


\section{ESPAÇAMENTO ECONÔMICO DE DRENOS LATERAIS E A DINÂMCA DO LENÇOL FREÁTICO SOBRE O RENDIMENTO DA CULTURA DE MILHO (Zea mays, L.)}

RAIMUNDO NONATO TÁVORA COSTA

Aprovado em 03.02.1995

Comissão julgadora:

Prof. Dr. Décio Eugênio Cruciani

ESALQ/USP

Prof. Dr. José Antônio Frizzone ESALQ/USP

Prof. Dr. Tarlei Aniel Botrel ESALQ/USP

Prof. Dr. João Carlos Cuny Saad FCAUUNESP

Prof. Dr. Abel Maia Genovez

UNICAMP

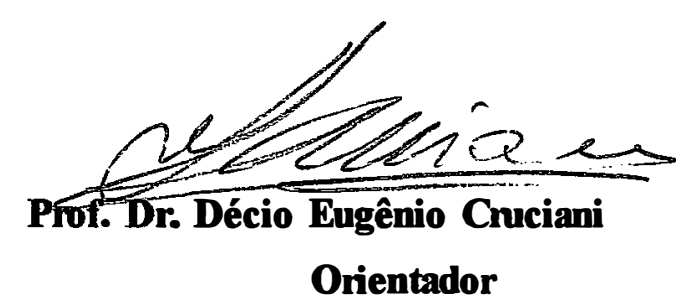


Aos meus pais LUIZ e CARMENSITA,

pelo exemplo de vida.

Aos meus irmãos,

SOCORRO, JOSÉ ROCHA e DOMINGOS SÁVIO

À ANGÉLICA e LUIZ EURICO,

esposa e filho, pelo amor

e compreensão

D E D I C O 


\section{AGRADECIMENTOS}

À Deus, pelas forças nos instantes mais difíceis;

Ao Departamento de Engenharia Agrícola da UFC, pela liberação concedida para a realização deste curso;

À Escola Superior de Agricultura "Luiz de Queiroz"- ESALQ/USP pelos ensinamentos;

À Coordenação de Aperfeiçoamento de Pessoal de Nível Superior CAPES, pela bolsa de estudo concedida durante o curso;

À Fortilit Conexões e Tubos de PVC(ex-Tupy Tubos e Conexões Ltda.), pela doação dos tubos de drenagem;

À Rhodia S.A. pela doação da manta de poliéster(Bidim) utilizada como envoltórios dos tubos de drenagem;

Ao Prof. Dr. Décio Eugênio Cruciani, pela orientação dada durante a realização deste trabalho;

Aos professores Dr. José Antônio Frizzone e Dr. Tarlei Arriel Botrel, pelas sugestões e críticas apresentadas;

À todos os professores do Curso de Pós-Graduação, em particular aos do Departamento de Engenharia Rural, pelos ensinamentos transmitidos;

Ao Professor Dr. Luís Carlos Uchôa Saunders, grande mestre e amigo, pelos primeiros ensinamentos em drenagem;

Aos colegas de curso, Vital, Marcus, Dirceu, João Zocoler, Sérgio, Ana Rita, pela amizade e convívio durante o curso; 
Aos funcionários do Departamento de Engenharia Rural, pela ajuda indispensável durante o trabalho;

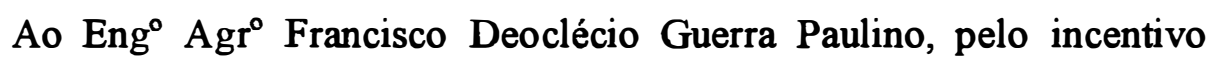
durante o curso;

Enfim, a todos que, direta ou indiretamente, contribuiram para a realização deste trabalho. 


\section{S U M Á R I O}

Página

LSTA DE FIGURAS . . . . . . . . . . . . . . . . . . . . . . . . . . . . . v viii

LSTA DE QUADROS . . . . . . . . . . . . . . . . . . . . . . . . . . . . . . $\quad$ ix

RESUMO . . . . . . . . . . . . . . . . . . . . . . . . . . . . . $\quad$.

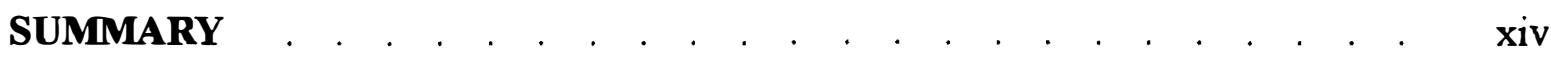

1. INTRODUÇÃO

2. REVISÃO DE LITERATURA $\quad . \quad$. . . . . . . . . . . . . . . . . . . . . . 04

2.1. Aspectos do excesso de umidade no solo _ . . . . . . . . . . . . . 04

2.2. Índices de estresse de água no solo $\quad . \quad$.

2.3. Níveis do lençol freático e resposta das culturas $\quad . \quad$. . . . . . . . . . 14

3. MATERIAL E MÉTOdOS . . . . . . . . . . . . . . . . . . . . . . . . . 23

3.1. Caracterização da área experimental . . . . . . . . . . . . . . . . 23

3.2. Características físico-hídricas e químicas do solo $\quad . \quad . \quad . \quad . \quad . \quad . \quad . \quad 25$

3.3. Instalação do experimento $\quad . \quad$. . . . . . . . . . . . . . . . . . . . . . 27

3.3.1. Sistema de drenagem subterrânea

3.3.2. Parcelas experimentais _. . . . . . . . . . . . . . . 31

3.4. Leituras dos poços de observação e descargas dos drenos laterais . 32

3.5. Condutividade hidráulica do solo saturado $\quad$. $\quad . \quad$. . . . . . . . . . . 34

3.6. Profundidade efetiva do sistema radicular $\quad . \quad$. . . . . . . . . . . 35

3.7. Flutuações do lençol freático $\quad$. . . . . . . . . . . . . . . . . . . . . . 36

3.8. Condução da cultura no campo $\quad$. . . . . . . . . . . . . . . . . . 39

3.9. Delineamento experimental . . . . . . . . . . . . . . . . . . . . 42 
4.1. Recarga do lençol freático

4.2. Análise dos caracteres de produção $\quad . \quad$. $\quad . \quad$.

4.3. Avaliação econômica do sistema de drenagem _ . . . . . . . . . . 51

4.4. Efeito do lençol freático no rendimento da cultura . . . . . . . . . 56

4.5. Avaliação hidráulica do sistema de drenagem subterrânea . . . . . 65

4.5.1. Perfis do lençol freático . . . . . . . . . . . . . 65

4.5.2. Descrição da rede de fluxo _. . . . . . . . . . . . . . 67

4.5.3. Eficiência de rebaixamento do lençol freático _ . . . . . . . 69

5. CONCluSÕes

REFERÊNCIAS BIBLIOGRÁFICAS . . . . . . . . . . . . . . . . . . . 74

APÊNDICE $\quad$. 


\section{LSTA DE FIGURAS}

Figura

Página

1 - Levantamento planialtimétrico do campo experimental . . . . . . 24

2 - Curvas características de umidade do solo da área experimental . . . 29

3 - Croqui da área experimental . . . . . . . . . . . . . . . . . . . 33

4 - Aspectos do sistema radicular da cultura . . . . . . . . . . . . . 37

5 - Vista geral da cultura estabelecida no campo . . . . . . . . . . 41

6 - Distribuição das precipitações no ciclo da cultura . . . . . . . . 45

7 - Aspectos das amostras de espigas em função dos tratamentos aplicados . $\quad 49$

8 - Dispersão de pontos entre produtividade relativa e profundidade média do

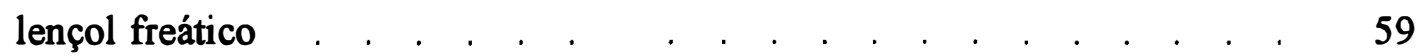

9 - Dispersão de pontos observados entre produtividade relativa e $\mathrm{SEW}_{20 . .}$. $\quad 60$

10 - Perfis do lençol freático durante o processo de drenagem . . . . . . . 66

11 - Planta das curvas de nível do lençol freático _ . . . . . . . . . . . . 68 


\section{LSTA DE QUADROS}

Quadro

Página

1 - Dados meteorológicos do Posto Agrometeorológico da ESALQ durante o experimento

2 - Características físico-hídricas do solo da área experimental

3 - Características químicas do solo da área experimental .

4 - Médias dos caracteres de produção do milho, em função dos tratamentos aplicados

5 - Análise de variância dos caracteres de produção

6 - Teste de Tukey para médias de tratamentos

7 - Coeficientes de correlação simples entre os caracteres de produção .

8 - Custos de implantação de 1,0 ha de drenagem subterrânea em função do espaçamento .

9 - Elementos econômicos em 1,0 ha de drenagem . . . . . . . . . 55

10 - Renda bruta da cultura de milho em 1,0 ha

11 - Dados econômicos para 1 ha de drenagem em função do espaçamento de drenos laterais

12 - Dados para análises do ajuste de equações

13 - Análises de regressão da produtividade relativa em função da profundidade média do lençol freático . 
14 - Análises de regressão da produtividade relativa em função do fator de estresse $\left(\mathrm{SEW}_{20}\right)$. . . . . . . . . . . . . . . . . . 62

\section{APÊNDICE}

Quadro

Página

1 - Precipitação pluvial(mm) no ciclo da cultura . . . . . . . . . . . . 83

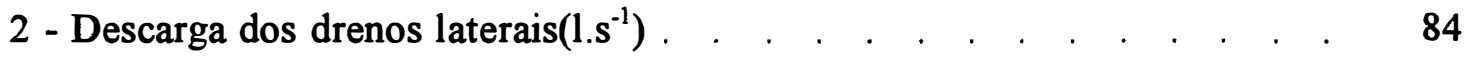

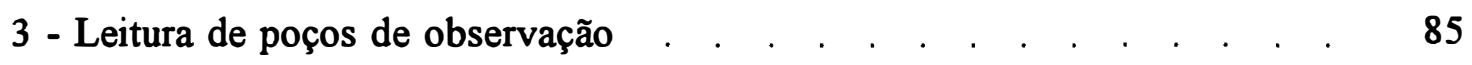

4 - Profundidades do lençol freático(m) . 


\title{
ESPAÇAMENTO ECONÔMICO DE DRENOS LATERAIS E A DINÂMICA \\ DO LENÇOL FREÁTICO SOBRE O RENDIMENTO DA CULTURA \\ DE MIILO (Zea mays, L.)
}

\author{
Autor : Raimundo Nonato Távora Costa \\ Orientador : Prof. Dr. Décio Eugênio Cruciani
}

\section{RESUMO}

O presente trabalho foi conduzido em uma várzea, no campo experimental de drenagem, do Departamento de Engenharia Rural da Escola Superior de Agricultura "Luiz de Queiroz", durante o período de novembro de 1992 a março de 1993. Teve por objetivos fornecer parâmetros que indiquem o espaçamento econômico para um sistema de drenagem agrícola e quantificar o efeito das flutuações do lençol freático no rendimento da cultura de milho.

Procurou-se, também, analisar o funcionamento do sistema de drenagem subterrânea, através de perfis do lençol freático, rede de fluxo e eficiência de rebaixamento do lençol freático.

Os drenos laterais, cujo comprimento era de $45,0 \mathrm{~m}$, foram instalados à profundidade média de $1,0 \mathrm{~m}$, com gradiente de declive de $0,003 \mathrm{~m} / \mathrm{m}$. Foram 
construídos com tubos de drenagem corrugados, flexíveis de PVC, diâmetro nominal de $0,1 \mathrm{~m}(\mathrm{DN} 100)$.

Os tratamentos avaliados consistiram em espaçamentos de drenos laterais a $10,0 \mathrm{~m}, 20,0 \mathrm{~m}$ e $30,0 \mathrm{~m}$. As variáveis utilizadas para testar a influência dos tratamentos, consistiram dos seguintes caracteres de produção da cultura de milho: altura de planta, peso de 100 grãos, peso médio das espigas, peso de grãos por espiga e produtividade.

Duas fileiras de poços de observação foram instaladas, sendo cada uma constituída de dezenove poços, com a finalidade de se proceder a caracterização do comportamento do lençol freático.

$\mathrm{Na}$ análise da dinâmica desse lençol em relação ao rendimento da cultura, foram realizados ajustes de equações relacionando produtividade relativa com a profundidade média do lençol freático e produtividade relativa com $\mathrm{SEW}_{20}$.

Os resultados revelaram que o espaçamento entre drenos laterais de 30,0m foi a melhor alternativa econômica, por apresentar maior valor de renda líquida anual. Verificou-se, também, a relevância dos custos fixos na análise de tomada de decisão.

$\mathrm{O}$ resultado da análise do índice de estresse $\mathrm{SEW}_{20}$ indicou que $\mathrm{o}$ rendimento da cultura não foi comprometido por excesso de umidade nos estádios analisados, devendo isso estar associado à variedade de milho estudada, que revelou possuir um sistema radicular muito superficial.

Não foi totalmente consistente a análise do rendimento da cultura em função da profundidade média do lençol freático, por não ter esta representado fielmente as posições e durações das oscilações do lençol freático. 
As cargas hidráulicas sobre os drenos, $48 \mathrm{~h}$ após a recarga do lençol freático, mostraram que os mesmos foram capazes de satisfazer ao critério de drenagem adotado (rebaixamento do lençol freático em 0,2m após 2 dias). Ao mesmo tempo, a direção do fluxo subterrâneo, no sentido dos drenos laterais, evidenciou uma locação e, portanto, um funcionamento adequado dos mesmos. 
ECONOMIC SPACING OF LATERAL DRAINS AND WATER TABLE

DYNAMICS UPON CORN (Zea mays, L.) YIELD

\author{
Author : Raimundo Nonato Távora Costa \\ Adviser : Prof. Dr. Décio Eugênio Cruciani
}

\title{
SUMMARY
}

This work was conduced on an artificially drained wet area at the experimental drainage field of the "Escola Superior de Agricultura Luiz de Queiroz", in the period from november 1992 to march 1993. Main objectives of the research were to identify an economic spacing of drains and to quantify the effects of water table fluctuations upon com (Zea mays, L.) yield.

Other parameters such as water table profiles, before and after recharge, flow-net, drainage efficiency, were also analyzed, reflecting the performance of the drainage system.

Drainage laterals $45.0 \mathrm{~m}$ long, installed at a mean depth of $1.0 \mathrm{~m}$, and slope of $0.003 \mathrm{~m} / \mathrm{m}$, in corrugated PVC tubes with nominal diameter of $0.1 \mathrm{~m}$. 
Treatments consisted on different spacings of $10.0 \mathrm{~m}, 20.0 \mathrm{~m}$ and $30.0 \mathrm{~m}$. To test the effects of the treatments the variables plant height, weight of 100 seeds, average weight of the ears, weight of the grains in one ear and grain production, were used.

Two batteries of observation wells, each with 19 wells, were use to monitor the fluctuation of the water table. To analyze water table dynamics in relation to crop yield, equations for productivity in relation to average depths of the water table and relative productivity as a function of $\mathrm{SEW}_{20}$, were adjusted.

Results showed that spacing of $30.0 \mathrm{~m}$ for laterals was the best economic choice. This indicates the importance of fixed costs in the composition of the total investment and in an economic analysis of the project.

Analysis of $\mathrm{SEW}_{20}$ index indicated that crop yield was not severely injured by excess water in the root zone, probabily due to the very shallow root system of corn plants.

Analyses of productivity of the crop as a function of fluctuations of the water table, were not entirely consistent, because duration of changes of the water table were not taken into account.

Hydraulic heads above the drains $48 \mathrm{~h}$ after the soil recharge showed they were effective in attending the drainage coefficient of the crop (drawdown of water level of $0,2 \mathrm{~m}$ in 2 days). Drains were located adequately in the field, as indicated by the flow net. 


\section{INTRODUÇÃO}

Extensas superficies agrícolas localizam-se em terrenos com problemas de drenagem. Em regiões de clima úmido, a elevação do lençol freático apresenta-se na estação chuvosa, dadas as precipitações mais intensas. $\mathrm{O}$ excesso de água no solo, devido aos altos níveis estacionais ou periódicos do lençol freático, tem-se constituído no principal risco para limitar a produtividade das culturas.

Conforme CURI et al. (1986), os solos de várzeas desenvolvem-se a partir de sedimentos oriundos de diversas fontes, cuja grande variabilidade horizontal e vertical influencia as camadas dos solos resultantes.

Essas áreas de baixada abrangem um total de trinta milhões de hectares no Brasil, conforme LAMSTER (1980). Qualitativamente, tais solos, por suas características químico-fisicas e condições topográficas, aliadas às técnicas de drenagem e irrigação, representam grande potencial para a produção de alimentos.

Em face do incremento populacional e do consequente aumento da demanda por alimentos, assume maior importância a utilização das várzeas como forma de contribuir para fomentar a produção agrícola. 
À ocupação desse potencial agrícola, todavia, deverá proceder-se de forma bastante racional, necessitando-se preliminarmente de um diagnóstico adequado(reconhecimento dos solos), bem como de informações de pesquisa, sobre condições locais de solo e clima, para melhor manejá-los.

Uma das maiores limitações aos projetos de drenagem tem sido a ausência de coeficientes confiáveis, que representem os requerimentos de drenagem das diversas culturas, sob condições locais. Alguns critérios têm sido mencionados na literatura, no entanto a maioria deles foi estabelecida com base em lisímetros, tendo-se mantido o lençol freático constante por um certo período, o que não representa, portanto, as condições existentes na prática.

Diversas pesquisas têm sido conduzidas com o objetivo de determinar a resposta das culturas às condições de excesso de água. Alguns desses estudos com a cultura do milho foram conclusivos quanto à redução na produtividade, quando o excesso de água ocorria durante o estádio vegetativo (JOSHI \& DASTANE, 1966; RITTER \& BEER, 1969; CHAUDHARY et al., 1975; SINGH \& GHILDYAL, 1980; KANWAR et al., 1988; MUKHTAR et al., 1990 e EVANS et al., 1990).

O delineamento de sistemas de drenagem, com base em parâmetros hidrodinâmicos do solo, poderá, muitas vezes, levar a erros grosseiros, tendo em vista a grande variabilidade espacial existente em solos de várzeas. No dimensionamento de um sistema de drenagem, tendo em vista a importância que os parâmetros de produção representam, o projetista deve utilizar, sempre que possível, dados obtidos com base em experimentos de campo, sob condições de flutuações do lençol freático, que representam as reais condições de estabelecimento das culturas. 
$\mathrm{O}$ conceito de $\mathrm{SEW}_{30}$ (soma do excesso de água) é descrito por WESSELING (1974) e representa a soma do valor excedente de água no solo, constituindose em um índice de estresse cuja finalidade é quantificar o efeito, sobre a produtividade, da ocorrência do lençol freático entre a superfície do solo e a profundidade de $0,30 \mathrm{~m}$.

Esse índice de estresse estabelece como excesso de água, a localização do lençol freático entre a superficie do solo e a profundidade de $0,30 \mathrm{~m}$, sendo considerados aditivos seus efeitos na produtividade das culturas. A metodologia já foi avaliada nos Estados Unidos, independente do porte do sistema radicular da cultura, caracterizando-se, portanto, como um critério de drenagem.

Na presente pesquisa, será concebido o conceito de SEW, e utilizada, como limite para fins de quantificação do excesso de água, a profundidade efetiva do sistema radicular da cultura.

Pelo exposto, na presente pesquisa duas hipóteses podem ser assumidas:

1. os parâmetros de produção da cultura podem indicar o espaçamento de drenos que proporciona o melhor rendimento econômico;

2. o índice SEW é um indicador capaz de evidenciar os efeitos, sobre o rendimento da cultura, das condições de estresse.

A presente pesquisa foi conduzida em condições de campo, tendo os seguintes objetivos:

a. fornecer parâmetros que indiquem o espaçamento econômico para um sistema de drenagem agrícola;

b. quantificar o efeito das flutuações do lençol freático no rendimento da cultura. 


\section{REVISÃO DE LITERATURA}

\subsection{Aspectos do excesso de umidade no solo}

Um teor de umidade disponível no solo, dentro de uma faixa ótima, constitui um dos parâmetros imprescindíveis para o desenvolvimento das culturas, facilitando o transporte de nutrientes através das raízes. Por outro lado, as condições de umidade excessiva na zona radicular são adversas para a maioria das culturas. Tais adversidades não correspondem, necessariamente, à presença direta de uma umidade excessiva por si só, mas sim, à deficiência no teor de oxigênio no solo, comprometendo o transporte de nutrientes através do sistema radicular e tornando as plantas mais suscetíveis às doenças e à deficiência nutricional. Dentro desse ambiente anaeróbico, verifica-se uma insuficiência de nitrogênio, devida à lixiviação ou à desnitrificação e ao desenvolvimento de substâncias tóxicas, conforme atestam estudos conduzidos por fisiologistas.

Basicamente, a falta de aeração constitui-se o principal agente de

injúrias às plantas. Algumas evidências disponíveis indicam que efeitos deletérios são também produzidos pela atividade microbiológica em condições anaeróbicas. A extensão de danos causados às culturas, por tais condições adversas, varia conforme a espécie 
vegetal, a duração da inundação, o estádio de desenvolvimento, além da temperatura prevalecente à época da inundação. Resultados de pesquisas nesse sentido serão descritos dentro desta revisão.

Em condições de campo, chuvas intensas resultam em condições temporárias de encharcamento, que determinam às raízes das plantas submeterem-se à respiração anaeróbica, produzindo, consequentemente, apenas uma pequena quantidade de energia, insuficiente para o metabolismo normal, resultando em morte das células das raízes. Ademais, o planejamento agrícola torna-se comprometido, tendo em vista que plantios atrasados, baixa emergência das culturas e reduzida efíciência nas operações da propriedade, constituem problemas típicos do excesso de água no solo.

Pesquisas básicas têm sido conduzidas para determinar a resposta das plantas a níveis baixos de umidade no solo; todavia existe uma lacuna na literatura de trabalhos que visem a um melhor entendimento da resposta das plantas às condições de excesso de umidade no solo. Por essa razão, pesquisas específicas que forneçam orientações confiáveis sobre a tolerância das culturas ao excesso de água no solo são particularmente necessárias, tendo em vista que eventos de chuvas frequentes causam flutuações do lençol freático próximo à superfície do solo.

Pesquisando sobre a resposta das culturas à drenagem em câmaras de vegetação com ambiente controlado, SCHILFGAARDE \& WILIAMSON (1965) ressaltam que dados sobre a variação da concentração de oxigênio no solo e sobre o movimento de água através da zona radicular constituem medidas necessárias para se estabelecer um critério útil para projetos de drenagem. Para tanto, considere-se que as plantas não respondem ao lençol freático por si só, mas preferivelmente ao nível de aeração na zona radicular e/ou à disponibilidade de umidade. 
GOINS et al. (1966), objetivando avaliar os efeitos interativos entre a altura do lençol freático e as classes texturais do solo em relação à efíciência do uso da água, ao desenvolvimento e à composição química da planta, observaram que as culturas de tomate e milho doce produziram significativamente mais matéria seca com o incremento em profundidade do lençol freático, e que esse incremento de produtividade foi maior em solo de textura fina. Concluíram, também, que o total de água consumida aumentou linearmente com a quantidade de matéria seca produzida.

A pesquisa permitiu também constatar que o aumento nas quantidades de $\mathrm{Ca}, \mathrm{Mg}$ e $\mathrm{N}$, observado nas plantas sobre maiores profundidades do lençol freático, refletia a maior disponibilidade de solo para exploração de raizes e que a disponibilidade de $\mathrm{N}$ deve também ter sido influenciada pelas condições de oxidação-redução nos solos úmidos.

De acordo com KRAMER (1969), existem muitas informações contraditórias em relação aos níveis de oxigênio e de dióxido de carbono que resultem em limitações para o crescimento das raízes. $\mathrm{O}$ autor atribui essas discrepâncias ao fato de os experimentos serem efetuados com diferentes espécies de plantas, em diversas etapas de desenvolvimento e sob condições de clima e solo as mais variadas possíveis. Além de tais fatores, os métodos utilizados em experimentos dessa natureza são os mais diversos. Em geral, parece que coeficientes de difusão de oxigênio inferiores a $20 \times 10^{-8} \mathrm{~g} / \mathrm{cm}^{2} . \mathrm{min}$ são inadequados e que valores superiores a $40 \times 10^{-8} \mathrm{~g} / \mathrm{cm}^{2} . \mathrm{min}$ são suficientemente altos para um crescimento adequado. Entretanto, WILLIAMSON (1964) relata ter obtido bons rendimentos em diversas culturas com coeficientes de difusão de oxigênio de $15 \times 10^{-8}$ $\mathrm{g} / \mathrm{cm}^{2} \cdot \min$ 
LAL \& TAYLOR (1969), pesquisando os efeitos de profundidades do lençol freático estático $(0,15$ e $0,30 \mathrm{~m})$, de inundações intermitentes, de dois níveis de $\mathrm{N}$ e de dois micronutrientes $(\mathrm{Zn}$ e $\mathrm{Cu})$ sobre a produtividade do milho, constataram que a absorção de $\mathrm{N}$ e Zn pelas plantas dessa cultura foi reduzida significativamente pelos níveis elevados do lençol freático e pelas inundações intermitentes. As concentrações, no solo, de $\mathrm{O}_{2}, \mathrm{CO}_{2}$ e $\mathrm{N}_{2}$ foram afetadas pelos níveis elevados do lençol freático. A percentagem de $\mathrm{O}_{2}$ foi reduzida, enquanto $\mathrm{CO}_{2}$ e $\mathrm{N}_{2}$ foi aumentada.

HILER et al. (1971) estudaram os efeitos do lençol freático estático sobre a difusão de oxigênio no solo e sobre a produtividade da cultura de sorgo. Concluíram que ocorreu uma redução drástica na produtividade, tanto do ponto de vista quantitativo quanto qualitativo, quando o lençol freático foi mantido a 0,30 e $0,60 \mathrm{~m}$, situação ainda mais clara se comparada com os tratamentos a 0,90 e $1,20 \mathrm{~m}$. De fato, considerável estresse de oxigênio na cultura ocorreu no tratamento com lençol freático a $0,30 \mathrm{~m}$, em que a taxa de difusão de oxigênio nunca excedeu a $20 \times 10^{-8} \mathrm{~g} / \mathrm{cm}^{2} \cdot \min$ na zona radicular, durante o ciclo da cultura. Detrimento com estresse de oxigênio também ocorreu no tratamento com lençol freático a $0,60 \mathrm{~m}$ - a taxa de difusão de oxigênio na zona radicular da cultura esteve na faixa de 40 a $90 \times 10^{-8} \mathrm{~g} / \mathrm{cm}^{2} \cdot \mathrm{min}$.

SINGH \& GHILDYAL (1980), trabalhando com cinco variedades de milho sob condições de campo e inundação do solo com várias durações, constataram que, durante os primeiros estádios de crescimento, uma inundação por $72 \mathrm{~h}$ reduziu significativamente a assimilação de $\mathrm{N}$ e $\mathrm{K}$ e aumentou a assimilação de $\mathrm{P}$ em todas as variedades, e que a assimilação de Ca e Mg não foi afetada. A taxa de difusão de oxigênio, de $83 \times 10^{-8} \mathrm{~g} / \mathrm{cm}^{2}$.min antes da inundação do solo, decresceu a quase zero após $72 \mathrm{~h}$ de inundação $\left(3,5 \times 10^{-8} \mathrm{~g} / \mathrm{cm}^{2} . \mathrm{min}\right)$. 
Em pesquisa de campo e de laboratório, visando a quantificar o efeito de inundações periódicas do sistema radicular na produtividade de milho e trigo, CRUCIANI (1981) constatou que as condições anaeróbicas caracterizadas durante a inundação radicular do milho, embora acentuadas, sugerem que, em condições naturais de campo, é muito provável serem mais severas, em virtude das diferenças peculiares entre a água utilizada nos experimentos e o lençol freático natural. A propósito, SINGH \& GHILDYAL (1980), em experimento descrito anteriormente, observaram que o $\mathrm{pH}$ do solo decresceu de 7,0 para 6,5 para um período de $24 \mathrm{~h}$ e a condutividade elétrica incrementou de 0,8 a $1,5 \mathrm{dS} / \mathrm{m}$ para um período de $72 \mathrm{~h}$ de inundação.

Segundo FAUSEY et al. (1985), a concentração de nutrientes e minerais não-nutrientes em plantas de milho é alterada por inundações cuja duração seja de 2 a 6 dias.

A difusão do oxigênio através de poros cheios de ar é aproximadamente 10.000 vezes mais rápida que através de poros cheios de água; consequentemente, a taxa de difusão de oxigênio através da água é frequentemente o fator limitante da respiração das rạizes. É o que entendem Clark \& Kemper ${ }^{1}$, citados por KANWAR et al. (1988).

PATWARDHAN et al. (1988) afirmam que a pesquisa clássica para projetos de drenagem ignora largamente a influência que a água capilar tem sobre a difusão de gases na zona radicular. Existiria, portanto, uma necessidade aparente de investigações sobre as relações entre a distribuição da água no solo, acima do lençol freático, e a do oxigênio na zona radicular.

${ }^{1}$ CLARK, F.E. \& KEMPER, W.D. Microbiological activity in relation to soil water and soil aeration. In: HAGEN, R.M., ed. Irrigation of agricultural lands. Agronomy, 11:472-480, 1967. 
KALITA \& KANWAR (1992), pesquisando o efeito do manejo do lençol freático sobre o processo fotossintético e sobre a produtividade do milho, constataram um aumento significativo nesta com o incremento em profundidade do lençol freático, desde 0,3 a $0,9 \mathrm{~m}$. Uma profundidade de 0,2 a $0,3 \mathrm{~m}$ reduziu significativamente a produtividade do milho na estação úmida. As relações entre taxas fotossintéticas e produtividade variaram para estações secas e úmidas e não foram conclusivas.

\section{2. Índices de estresse de água no solo}

A complexidade das relações, envolvendo produtividade das culturas e conteúdo de umidade no solo, não é bem entendida, constituindo-se uma limitação para critérios adequados de drenagem(BOUWER, 1974).

Recentemente, efeitos do excesso de água no solo, sobre o desenvolvimento das plantas, têm recebido renomada atenção. Por essa razão, os pesquisadores vêm desenvolvendo métodos para analisar os efeitos dos sistemas de drenagem sob condições de excesso de água e para predizer seus efeitos sobre as produtividades das culturas.

O conceito de $\mathrm{SEW}_{30}$ (somatório do excesso de água) foi desenvolvido por Sieben ${ }^{2}$ e descrito por WESSELING (1974), e representa a soma do valor excedente de água no solo, conhecido, como a "soma do excesso de água", para quantificar o efeito, sobre

${ }^{2}$ SIEBEN, W.H. Het verban tussen ontwatering en opbrengst bi j de jonge zavelgronden in de Noordoostpolder. Van Zee tot Land. 40, Tjeenk Willink V. Zwolle, The Netherlands, 1964. 
a produtividade, da ocorrência do lençol freático na zona radicular da cultura. Expressa-se da seguinte forma:

$$
S E W_{30}=\sum_{i=1}^{n}\left(30-x_{i}\right) . . . . . .
$$

sendo:

$\mathrm{x}_{\mathrm{i}}$ - profundidade do lençol freático abaixo da superfície do solo no dia $\mathrm{i}$, em $\mathrm{cm}$;

n - número de dias na estação de crescimento.

O método estabelece o critério de que números negativos dentro da somatória sejam negligenciados, ou seja: só serão computados valores de $\mathrm{x}_{j}$ menores que 30.

Em razão da flutuação contínua do lençol freático, o $\mathrm{SEW}_{30}$ pode ser mais precisamente expresso como:

$$
S E W_{30}=\int_{0}^{T} f(x) d t \ldots . . . . .
$$

sendo:

$f(x)=30-x ;$ para $x<30$

$f(x)=0 ;$ para $x>30$.

T - duração da estação de crescimento;

$t$ - tempo em dias;

$\mathrm{x}$ - profundidade do lençol freático $\mathrm{em} \mathrm{cm}$.

O conceito de SDI(índice de estresse diário) foi introduzido, por HILER (1969), como um recurso para quantificar, cumulativamente, o efeito de estresse imposto 
sobre uma cultura durante a estação de crescimento. O SDI é determinado por um fator de estresse diário(SD) e um fator de suscetibilidade da cultura(CS). O SD, sendo uma medida do grau de estresse imposto sobre uma cultura, reflete a intensidade e duração do estresse. O CS, sendo uma medida da suscetibilidade da cultura para uma unidade de estresse, é função da cultura e de seu estádio de desenvolvimento.

Conceitualmente o SDI pode ser escrito como:

$$
S D I=\sum_{i=1}^{n}\left(S D_{i}, C S_{i}\right) \cdot \cdot \cdot \cdot \cdot \cdot \cdot \cdot
$$

sendo:

n - número de períodos de crescimento;

SD- fator de estresse diário da cultura no período i;

CS- fator de suscetibilidade da cultura no período $i$.

$\mathrm{O}$ parâmetro $\mathrm{SEW}_{30}$ é normalmente utilizado como fator de estresse diário da cultura, em estudos que envolvem o índice de estresse diário.

O fator de suscetibilidade da cultura é determinado experimentalmente, tomando-se por base o nível crítico de estresse ao qual a cultura foi submetida, durante cada estádio de desenvolvimento fisiológico, bem como a quantificação de sua resposta à produtividade.

O fator de suscetibilidade para cada estádio de desenvolvimento da cultura é definido por HILER (1969) e expresso como: 


$$
C S_{i}=\frac{X-Y_{i}}{X} \cdot \cdot \cdot \cdot \cdot \cdot \cdot \cdot \cdot \cdot
$$

sendo:

$X$ - produtividade da cultura na ausência de estresse;

$\mathrm{X}_{\mathrm{i}}$ - produtividade da cultura quando sujeita ao estresse crítico no estádio de crescimento $\mathrm{i}$.

A importância do fator CS no conceito de SDI é definir a suscetibilidade da cultura, em algum estádio de crescimento, a uma unidade de estresse. Não é o valor absoluto do fator CS que importa, mas preferivelmente valores relativos para vários estádios de crescimento.

De acordo com HILER \& CLARK (1971), o fator de suscetibilidade da cultura é uma função das espécies, estádio fenológico da cultura e indica a sua suscetibilidade para dada magnitude de SD.

Os pesquisadores relatam que um método sofisticado para determinação de CS é relacionar carbono acumulado por dia ou taxa fotossintética e SD. Uma outra metodologia para caracterização de CS é plotar a produtividade da cultura(abscissa) versus SD acumulado para um dado período de crescimento(ordenada). Portanto, o valor de CS, para cada período, seria a declividade da curva, relacionada para aquele período, isto é:

$$
C S_{i}=\frac{\Delta S D_{i}}{\Delta_{\text {produtividade }}} \cdot . . . . . . . .
$$

sendo $i$ o período de crescimento. 
SUDAR et al. (1979) sugerem que fatores de suscetibilidade da cultura ao estresse de umidade podem ser aproximados, no caso de algumas culturas, pela existência de dados sobre a resposta de produtividade ao estresse de seca.

HARDJOAMIDJOJO et al. (1982), em pesquisa com a cultura do milho sob condições de excesso de umidade, detectaram uma forte relação entre YR(produtividade relativa do milho) e SDI. Nessa pesquisa, as produtividades absolutas do milho foram transformadas para produtividades relativas, tomando-se a razão da produtividade medida para cada parcela pela produtividade potencial. A produtividade potencial foi tomada como a produtividade mais alta. Os autores entendem que o uso da produtividade relativa é preferível ao da produtividade absoluta, uma vez que aquela representa uma tentativa de eliminar os efeitos de outros fatores que não os tratamentos de drenagem.

Em três anos de estudo sobre a resposta do milho às condições naturais de flutuação do lençol freático, KANWAR et al. (1988) investigaram a influência das condições de excesso de água no solo sobre a produtividade do milho em cinco diferentes estádios fenológicos. Eles verificaram que a produtividade foi reduzida significativamente quando o valor de $\mathrm{SEW}_{30}$ para o $1^{\circ}$ estádio de desenvolvimento excedeu $40 \mathrm{~cm}$.dias. Observaram, também, que a produtividade do milho decresceu linearmente com o incremento dos valores de $\mathrm{SEW}_{30}$.

Em pesquisa para determinar o fator CS para o milho, MUKHTAR et al. (1990), com base nos dados de produtividade média de dois anos, chegaram aos valores de 0,64 para o início do período vegetativo, 0,44 para o final do período vegetativo, 0,15 para o estádio de florescimento e 0,19 para o estádio de maturação. 
Por outro lado, CARTER et al. (1990), pesquisando sobre a produtividade do milho doce em várias durações de excesso de água no solo, durante os estádios vegetativo e de florescimento, determinaram fatores de suscetibilidade da cultura baseados no peso do milho comercializável, da ordem de 0,55 e 0,45 respectivamente. Tais fatores indicam que o milho doce é altamente suscetível ao estresse de excesso de água no solo, durante ambos os estádios de crescimento e, usualmente mais, durante o estádio vegetativo.

Já EVANS et al. (1990) sugerem que fatores de suscetibilidade da cultura ao estresse de umidade podem ser aproximados para algumas outras culturas, pela existência de dados sobre a resposta de produtividade destas ao estresse de seca.

Utilizando tratamentos de submersão na superfície do solo e profundidade do lençol freático a $0,15 \mathrm{~m}$, conjugados com quatro níveis de estresse de excesso de água equivalentes a 90, 180, 270 e $360 \mathrm{~cm}$.dias, AKMAD et al. (1992) verificaram que a matéria seca do milho decresceu linearmente com o incremento dos níveis de estresse para ambos os tratamentos, mas que o tratamento submersão na superfície decresceu mais com cada incremento no nível de estresse, se comparado ao tratamento com profundidade do lençol freático a $0,15 \mathrm{~m}$ da superfície.

\subsection{Níveis do lençol freático e resposta das culturas}

$\mathrm{Na}$ literatura, existe uma escassez de estudos, para as nossas condições, em relação aos efeitos da profundidade do lençol freático sobre a produtividade. Embora 
experimentos de laboratório e de campo tenham sido conduzidos nesse sentido em outras regiões, a transferência desses resultados de uma localidade para outra não é recomendável, tendo em vista as condições específicas de cada local.

TOVEY (1964), em sua pesquisa com alfafa, a partir de lisímetros, concluiu que o excesso de água deve ser removido da zona radicular da cultura dentro de três dias, para assegurar ótima produtividade. Verificou, também, que o sistema radicular da alfafa vai se tornando progressivamente deteriorado, com maior intensidade para condições de flutuação ou intervalos de submersão excedentes a quatro dias.

WILLIAMSON \& SCHILFGAARDE (1965), trabalhando com as culturas da soja, do repolho, do milho, do sorgo granífero e do milheto, em lisímetros, com lençóis freáticos constantes, estabelecidos de dez dias a três semanas após a semeadura, e mantidos durante todo o ciclo da cultura, concluíram que as produtividades geralmente aumentaram com o incremento em profundidade do lençol freático. Sugerem, também, com base nos dados de produtividade obtidos, que algumas culturas com sistema radicular profundo, como o milho, requerem um lençol freático mais profundo do que culturas com sistema radicular raso, tais como a soja.

Em um experimento com milheto submetido a lençóis freáticos estáticos, às profundidades de $0,15,0,30,0,46,0,61,0,76,0,91$ e 1,02m abaixo da superfície do solo, WILLIAMSON et al. (1969) observaram um incremento da produtividade com a profundidade do lençol freático até $0,76 \mathrm{~m}$. Os dados de produtividade sugerem que a disponibilidade de $\mathrm{O}_{2}$ foi baixa em uma porção da zona radicular onde os lençóis freáticos estavam abaixo de $0,76 \mathrm{~m}$ da superfície do solo. 
RITTER \& BEER (1969) pesquisaram, em condições de campo, a resposta do milho submetido a inundações por $24,48,72$ e $96 \mathrm{~h}$, com uma lâmina de água mantida sobre a superfície do solo em torno de seis polegadas. $\mathrm{O} 1^{\circ}$ tratamento foi aplicado quando o milho estava com altura de seis polegadas, e os demais, com trinta polegadas e no estádio de formação das espigas(embonecamento). Dois níveis de nitrogênio foram usados nas parcelas. Concluíram, com base nos dados de produção de grãos, que as produtividades do milho são mais afetadas quando a inundação ocorre no estádio inicial de desenvolvimento. Observaram, também, que as produtividades das parcelas com níveis altos e baixos de nitrogênio foram reduzidas em 20 e $35 \%$ respectivamente, quando as parcelas foram inundadas por $72 \mathrm{~h}$, e que, nos estádios finais de desenvolvimento, o efeito da inundação foi pequeno, exceto para as parcelas com baixo nível de nitrogênio. Segundo os autores, o estádio de desenvolvimento em que ocorre a inundação e a duração do período de inundação são fatores importantes na avaliação dos danos causados ao milho, e que, por conseguinte, a altura de submersão não deve ser o único critério utilizado para estabelecer danos por inundações.

De acordo com WILLIAMSON \& KRIZ (1970), as máximas produtividades das culturas estão associadas a uma profundidade ótima do lençol freático, e tal profundidade ótima depende do tipo de solo, do tipo de cultura, do clima e da irrigação.

HOWELL \& HILER (1974) avaliaram os efeitos de períodos de inundação sobre a resposta das culturas de milho, algodão, sorgo e ervilha. Observaram que a sobrevivência das plantas e produção de matéria seca, um mês após a semeadura, foram 
drasticamente reduzidas pelos períodos de inundação maiores que 02(dois) dias, durante o estádio de desenvolvimento de plântulas.

Já FOLLETT et al. (1974a) estudaram, em condições de campo, a combinação desejável da quantidade de irrigação e do grau de drenagem para produtividade de milho, beterraba e alfafa em um solo arenoso, com um lençol freático em declínio. As irrigações eram aplicadas semanalmente de $0,0,5,1,0$ e 1,5 vezes o requerimento de água das culturas. Concluiu-se que as produtividades máximas de todas as culturas ocorreram quando o lençol freático variou entre 0,69 e $0,92 \mathrm{~m}$, independentemente dos requerimentos de irrigação aplicados.

FOLLETT et al. (1974b) pesquisaram a distribuição das raízes do milho em profundidade, sob condições de lençol freático em declínio, num solo arenoso. As profundidades do lençol freático variaram de 1,33 a $2,64 \mathrm{~m}$. Observou-se que o crescimento foi máximo para profundidades intermediárias do lençol freático e que a distribuição de raízes em profundidade indicou que requerimentos de água para milho, nesses solos arenosos, devem ser supridos para uma zona radicular com profundidade máxima de aproximadamente $1,00 \mathrm{~m}$. Entendem os autores que esse parâmetro é de suma importância para propor um manejo adequado em um sistema de produção com milho.

CHAUDHARY et al. (1975) estudaram a resposta do milho a quatro profundidades estáticas do lençol freático $(0,60,0,90,1,20$ e 1,50m), afetadas pelas chuvas na estação de crescimento, e submersão variando de 1 a 6 dias. Usaram um cilindro de metal de $0,58 \mathrm{~m}$ de diâmetro e altura de $1,83 \mathrm{~m}$, contendo um solo franco argiloso, durante dois anos. Concluíram que a submersão durante o início da estação de desenvolvimento foi 
mais prejudicial que durante o final do ciclo, e que a submersão prolongada reduziu significativamente a concentração de N, P e K no grão de milho.

Já REICOSKY et al. (1976) trabalharam com a cultura de milho em um solo areno-argiloso, subsolado até a profundidade de $0,38 \mathrm{~m}$ e compararam com o que foi cultivado convencionalmente. Verificaram, no cultivo do ano seguinte, que, com um lençol freático a $0,80 \mathrm{~m}$ da superfície do solo, a subsolagem resultou em maior profundidade de enraizamento do milho, provocando, consequentemente, maior habilidade para a planta na utilização de água capilar acima do lençol freático.

Por outro lado, HOWELL et al. (1976) conduziram pesquisa em lisímetros, tendo como objetivo avaliar a resposta do sorgo a períodos de inundação de 12 dias, com lâmina de $0,06 \mathrm{~m}$, no início do estádio vegetativo, início da floração e estádio de crescimento da panícula. Observaram reduções na produtividade, da ordem de 30 e $26 \%$, para o início do estádio vegetativo e início da floração, respectivamente. Observaram, também, que na fase de crescimento da panícula não ocorreu redução na produtividade. Segundo os autores, a inundação pode causar redução na produtividade em razão de danos físicos à cultura tais como parada temporária de desenvolvimento e aumento do tempo de maturação.

Informações sobre respostas das culturas são necessárias para combinações entre profundidades do lençol freático e tratamentos de irrigação, visando a projetar adequadamente sistemas de drenagem e irrigação. Nesse sentido, BENZ et al. (1978) conduziram um experimento de campo em um solo areno-argiloso, estabelecendo as culturas de milho, beterraba e alfafa. Os tratamentos consistiram de três profundidades do 
lençol freático e quatro aplicações de irrigação por aspersão, semanalmente, nas quantidades desde zero(somente precipitação) a 1,5 vez a quantidade requerida. Observaram que as produtividades das culturas em lençol freático mais profundo( $2,3 \mathrm{~m})$, aumentaram com as quantidades de irrigação, mas nunca se igualaram àquelas com lençol freático raso(1,2m), complementado com irrigação.

ZOLEZZI et al. (1978) estudaram os efeitos de inundações sobre a produtividade de sorgo granífero, utilizando tratamentos de inundação no estádio vegetativo final para 7, 12 e 17 dias, com lâmina de $0,08 \mathrm{~m}$. Observaram que, em todos os tratamentos, houve um decréscimo de área foliar e altura da planta e que as reduções na produtividade foram de $21,2,12,9$ e 2,5\% para os tratamentos com 17,12 e 7 dias, respectivamente, comparados com o tratamento-testemunha.

CRUCIANI (1981) conduziu pesquisa em casa-de-vegetação e campo experimental, tendo como objetivos estudar as respostas de uma variedade de trigo e de milho, a inundações completas do sistema radicular, no intuito de quantificar os efeitos produridos em fases distintas do ciclo vegetativo dessas culturas. Dentre outras conclusões, verificou que a fase mais crítica para as duas culturas foi durante o florescimento, tendo havido decréscimo de produtividade em relação às testemunhas de 32,6, 39,2 e 43,5\% para o trigo e de 43,0,60,6 e 68,9\% para o milho, com respectivamente 3,6 e 9 dias de inundação. Sugere, ainda, o pesquisador que o tempo de drenagem da zona radicular dessas culturas deva ser inferior a três dias.

Em pesquisa com o objetivo de avaliar a produtividade da alfafa, em função da profundidade do lençol freático e dos níveis de irrigação, BENZ et al. (1982) 
conduziram experimento com lisímetros, em parcelas de campo de solo arenoso. Os resultados mostraram que a profundidade ótima do lençol freático para produtividades máximas foi de $1,5 \mathrm{~m}$ e que a irrigação não foi necessária quando o lençol freático foi mantido nessa profundidade ótima.

PINTO (1985) conduziu pesquisa com feijão, cultivado em colunas de solo mineral de várzea, construidas de tubos de PVC rígido, com dimensões de $1,20 \mathrm{~m}$ de comprimento e $0,15 \mathrm{~m}$ de diâmetro externo. Os tratamentos aplicados consistiram de quatro profundidades estáticas do lençol freático: $0,25,0,40,0,55$ e $0,80 \mathrm{~m}$ em relação à superfície do solo, com e sem irrigação por superfície, mais um tratamento irrigado por superfície e sem a presença do lençol freático. $\mathrm{O}$ autor concluiu que a produtividade e os componentes de produção do feijoeiro, em geral, não foram afetados pela profundidade do lençol freático, exceto a altura das plantas, e que o uso da subirrigação, com lençol freático estático como única fonte de água para a zona radicular, resultou em baixa produtividade, em comparação com os tratamentos irrigados por superfície.

ALVINO \& ZERBI (1986) conduziram experimento em condições de campo, em solo de aluvião, sob condições de precipitações naturais e irrigação, visando a verificar o efeito do lençol freático sobre parâmetros de produção da cultura do milho. Os dados mostraram que a produtividade do milho decresceu com o aumento da profundidade do lençol freático, fazendo-se perceber essa tendência mais rapidamente sob condições de chuva que de irrigação. Segundo os autores, a produtividade foi aumentada com a irrigação, mesmo para lençóis freáticos $\operatorname{rasos}(0,6 \mathrm{~m})$, via um aumento no número de sementes por espiga e reduzida senescência foliar. 
Em experimento de campo, instalado em um solo gley pouco húmico de várzea, LIMA et al. (1986) estudaram os efeitos de níveis de profundidade do lençol freático sobre parâmetros de produção da cultura do feijoeiro, variedade "Preto 60 dias". Os níveis do lençol freático, obtidos pela aplicação contínua de água no solo, compreenderam as faixas de $0,55-0,60,0,61-0,66,0,67-0,72,0,73-0,78,0,79-0,84$ e $0,85-0,90 \mathrm{~m}$. Observaram tais autores que não houve diferença estatística entre os níveis freáticos de 0,55 a $0,84 \mathrm{~m}$ para produtividade, número de vagens por planta e número de grãos por vagem. Verificaram, também, que a produtividade no nível freático de $0,55-0,60 \mathrm{~m}$ foi $98 \%$ superior à do nível de $0,85-0,90 \mathrm{~m}$ e que o lençol freático com profundidade superior a $0,84 \mathrm{~m}$ proporcionou menor desenvolvimento vegetativo das plantas. Enfim, esses pesquisadores demonstram que o uso da subirrigação para o feijoeiro, como fonte de suprimento de água para as raízes, pode mostrar-se viável, desde que o lençol freático seja mantido entre 0,55 e $0,84 \mathrm{~m}$ de profundidade.

Já COOPER et al. (1991) avaliaram o potencial de produtividade da soja em condições de campó, submetida a cultura a um sistema de subirrigação/drenagem em um solo de textura franco-argilosa, comparando tal situação com um tratamento nãoirrigado(profundidade do lençol freático variando naturalmente). $\mathrm{O}$ lençol freático do sistema de subirrigação/drenagem foi mantido na faixa de $0,25 \mathrm{~m}$ sobre a linha de drenos e $0,53 \mathrm{~m}$ no ponto médio entre drenos, os quais eram espaçados de $6,0 \mathrm{~m}$. Verificaram, com base nos dados de produtividade da soja, que o sistema de subirrigação/drenagem apresentou um rendimento $58 \%$ superior ao sistema não irrigado. De acordo com os autores, o manejo adequado de um sistema de subirrigação/drenagem pode permitir a obtenção de elevadas produtividades. 
ANDRADE (1991), por sua vez, estudou os efeitos das profundidades estáticas do lençol freático a $0,30,0,50,0,70$ e $0,90 \mathrm{~m}$, em lisímetros preenchidos com um Latossolo Vermelho-Amarelo Distrófico, sobre a evapotranspiração e componentes de produção da cultura do milho-doce. Concluiu que a produção de espigas verdes aumentou linearmente com a profundidade do lençol freático, e que a lâmina de evapotranspiração total para todas as profundidades freáticas, após 45 dias da semeadura, foi maior do que a evaporação total do tanque Classe A.

KANDIL \& WILLARDSON (1992) desenvolveram metodologia que permite, através de análise de regressão linear múltipla de frequências de profundidades do lençol freático, estimar produtividades de culturas afetadas por diferentes níveis do lençol freático. Entendem, também, os pesquisadores que dados de produtividade podem ser utilizados para determinar o espaçamento de drenos, no intuito de obter-se a melhor produtividade.

Por fim, ANDRADE \& REIS (1992) conduziram experimento em solo Gley Húmico, para avaliar a influência de diferentes profundidades do lençol freático na produtividade das culturas de soja, milho e arroz. $\mathrm{O}$ experimento foi locado entre dois drenos espaçados $15,0 \mathrm{~m}$ entre si, com o dreno superior cheio de água, servindo como fonte de recarga, e o dreno inferior mantido vazio, com a finalidade de estabelecer um gradiente na linha freática. Verificaram que os maiores rendimentos de milho foram obtidos onde o lençol freático se manteve entre 0,60 e $0,70 \mathrm{~m}$ de profundidade, e que os rendimentos, para as culturas da soja e do arroz, não apresentaram diferença significativa em relação à profundidade do lençol freático. 


\section{MATERIAL E MÉTODOS}

\subsection{Caracterização da área experimental}

A presente pesquisa foi conduzida em uma várzea, no campo experimental de drenagem, pertencente ao Departamento de Engenharia Rural da ESALQ(Escola Superior de Agricultura "Luiz de Queiroz"), Piracicaba-SP, no período de novembro de 1992 a março de 1993.

A área experimental caracteriza-se por apresentar um relevo plano, com leves ondulações, drenagem interna deficiente, prestando-se preliminarmente para o cultivo de arroz sob regime de irrigação por inundação, exclusivamente. A problemática de drenagem na área experimental era agravada pela contribuição das águas provenientes de uma encosta situada na divisa, tendo-se, por esse motivo, construído um terraço de pé de encosta, com a finalidade de promover o escoamento das águas superficiais. A área útil do experimento compreendeu $8100 \mathrm{~m}^{2}$, sendo seu solo classificado como Gleissolo Eutrófico, horizonte A moderado, textura argilosa a média(Typic Haplaquet), com inclusões de solos vérticos (Vertic Haplaquet), conforme mapeamento de solos da ESALQ. O levantamento planialtimétrico do campo experimental é mostrado na Figura 1. 


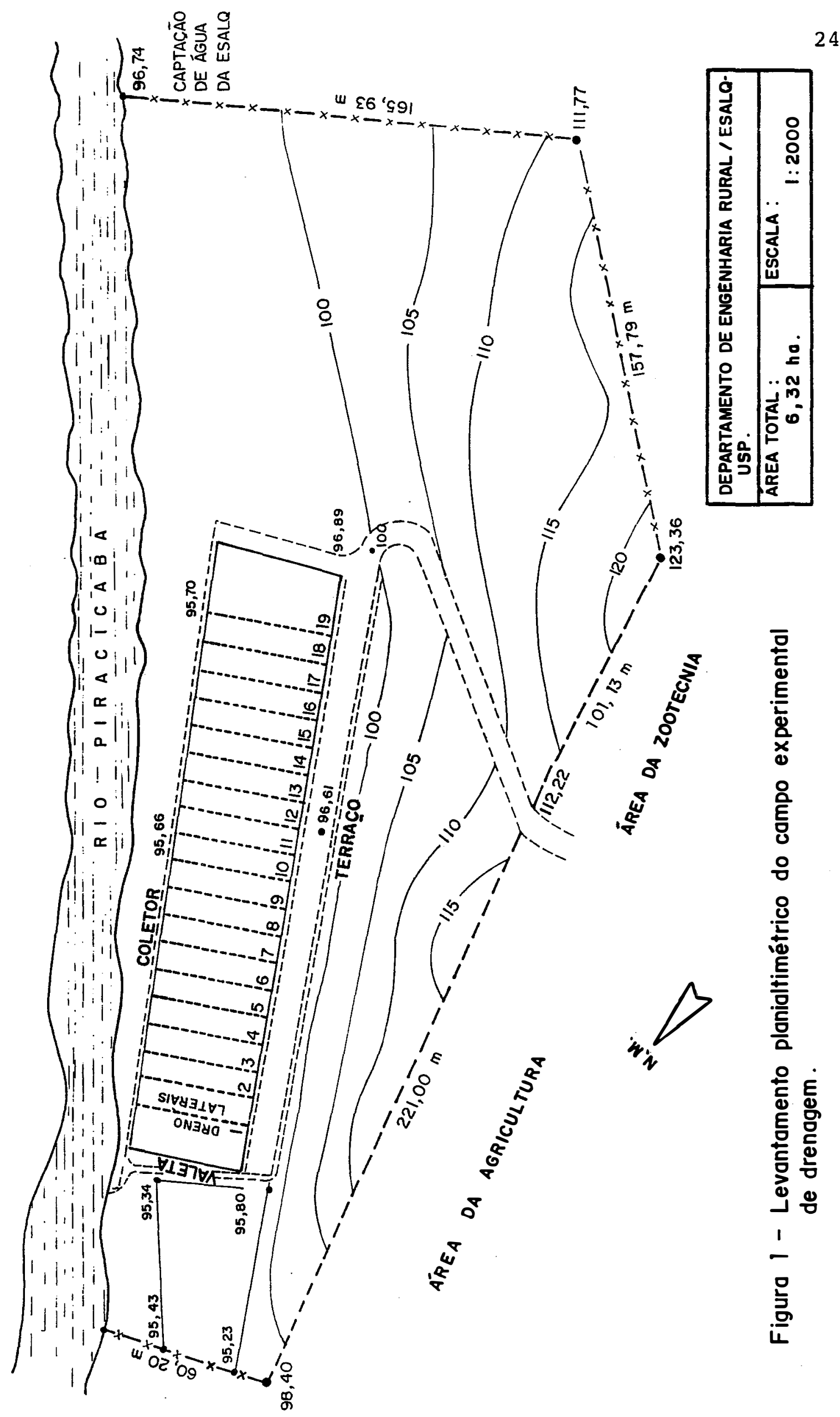


O local experimental possui, como coordenadas geográficas, latitude de $22^{\circ} 42^{\prime} 30^{\prime \prime}$ sul, longitude de $47^{\circ} 38^{\prime} 00^{\prime \prime}$ oeste e altitude de 546 metros. Apresenta uma caracterização climática média anual de $1247 \mathrm{~mm}$ de precipitação normal, $20,8^{\circ} \mathrm{C}$ de temperatura e $69 \%$ de umidade relativa. O clima da região, pela classificação climática proposta por KOPPEN, é do tipo mesotérmico $\mathrm{CWa}$, isto é, subtropical úmido, com estiagem no inverno, temperatura média do mês mais frio inferior a $18^{\circ} \mathrm{C}$ e a do mês mais quente superior a $22^{\circ} \mathrm{C}$, também denominado tropical de altitude, conforme CAMARGO et al. (1974). De acordo com CERVELLINI et al. (1973), a maior parte da precipitação ocorre no período de novembro a fevereiro, principalmente com chuvas de alta intensidade e curta duração. Os dados meteorológicos, coletados no Posto Agrometeorológico localizado nas proximidades da área experimental, são mostrados no Quadro 1, sendo os registros de precipitação pluvial coletados "in loco", através de pluviômetro previamente instalado, conforme mostra o Quadro 1 do Apêndice.

\subsection{Características físico-hídricas e químicas do solo}

$\mathrm{Na}$ instalação do experimento, coletaram-se, ao longo do perfil do solo até a profundidade de $1,00 \mathrm{~m}$, amostras com estruturas deformadas e não-deformadas, com a finalidade de se determinarem as principais características físico-hídricas e químicas de interesse para a pesquisa. 
Quadro 1. Dados meteorológicos do Posto Agrometeorológico da ESALQ durante o experimento.

\begin{tabular}{|c|c|c|c|c|c|}
\hline \multirow{2}{*}{$\begin{array}{l}\text { Elementos } \\
\text { Meteorológicos }\end{array}$} & \multicolumn{2}{|c|}{1992} & \multicolumn{3}{|c|}{1993} \\
\hline & Nov. & Dez. & Jan. & Fev. & Mar. \\
\hline \multicolumn{6}{|l|}{ Temperatura $\left({ }^{\circ} \mathrm{C}\right)$} \\
\hline Máxima & 33,80 & 34,30 & 36,40 & 31,80 & 34,80 \\
\hline Mínima & 12,80 & 13,00 & 18,00 & 16,60 & 17,20 \\
\hline \multicolumn{6}{|l|}{ Umidade } \\
\hline relativa (\%) & 77,50 & 74,00 & 81,50 & 85,20 & 79,60 \\
\hline \multicolumn{6}{|l|}{ Evaporação(mm) } \\
\hline Tanque Classe A & 131,10 & 199,90 & 167,20 & 111,00 & 136,20 \\
\hline Precipitação(mm) & 153,40 & 142,20 & 179,90 & 232,10 & 39,70 \\
\hline $\begin{array}{l}\text { Velocidade do } \\
\text { vento }\left(\mathrm{m} \cdot \mathrm{s}^{-1}\right)\end{array}$ & 2,68 & 2,52 & 2,00 & 2,00 & 1,81 \\
\hline
\end{tabular}

As amostras foram coletadas em subcamadas de $0,25 \mathrm{~m}$, com três repetições, entre os blocos III e IV onde localizavam-se drenos espaçados a $30,0 \mathrm{~m}$. Na determinação da composição granulométrica do solo, utilizou-se a metodologia do hidrômetro, proposta por BOUYOUCOS (1926), sendo que a massa específica real foi 
determinada pelo método do picnômetro. A porosidade total(PT) foi estimada em função das massas específicas global e real. A estimativa da porosidade drenável $(\alpha)$ foi procedida pela diferença entre a porosidade total e a umidade equivalente $\left(\theta^{*}\right)$, à tensão de $3 \times 10^{4} \mathrm{~Pa}$.

As características físico-hídricas do solo são apresentadas no Quadro 2. As curvas características de umidade das camadas do perfil, mostradas na Figura 2, foram obtidas através de mesa de tensão, no intervalo de $10^{3}$ a $4 \times 10^{3} \mathrm{~Pa}$, e Câmara de Richards, com placas porosas para tensões de $10^{4}$ a $10^{5} \mathrm{~Pa}$. A camada $0,50-0,75 \mathrm{~m}$, de textura franco-argilosa, apresenta menor porosidade drenável e maior retenção de água, o que constitui uma disparidade, que deve está ligada ao fato de as amostras não terem sido coletadas em um mesmo local, dada a variabilidade espacial existente em solos de várzeas.

As análises químicas do solo, mostradas no Quadro 3, demonstram que o mesmo apresenta uma boa fertilidade, tendo em vista valores elevados de CTC nas camadas superficiais, estando também bem provido de fósforo, potássio, cálcio e magnésio. Apresenta uma reação ligeiramente ácida $\left(\mathrm{p}_{\mathrm{H}}=6,4\right)$, sem problemas de alumínio.

\subsection{Instalação do experimento}

No planejamento da pesquisa, seguiram-se duas etapas distintas: inicialmente, a instalação de um sistema de drenagem subterrânea, e, por último, o estabelecimento e a condução de uma cultura de milho, de acordo com o procedimento experimental proposto. 
Quadro 2. Características físico-hídricas do solo da área experimental ${ }^{3}$

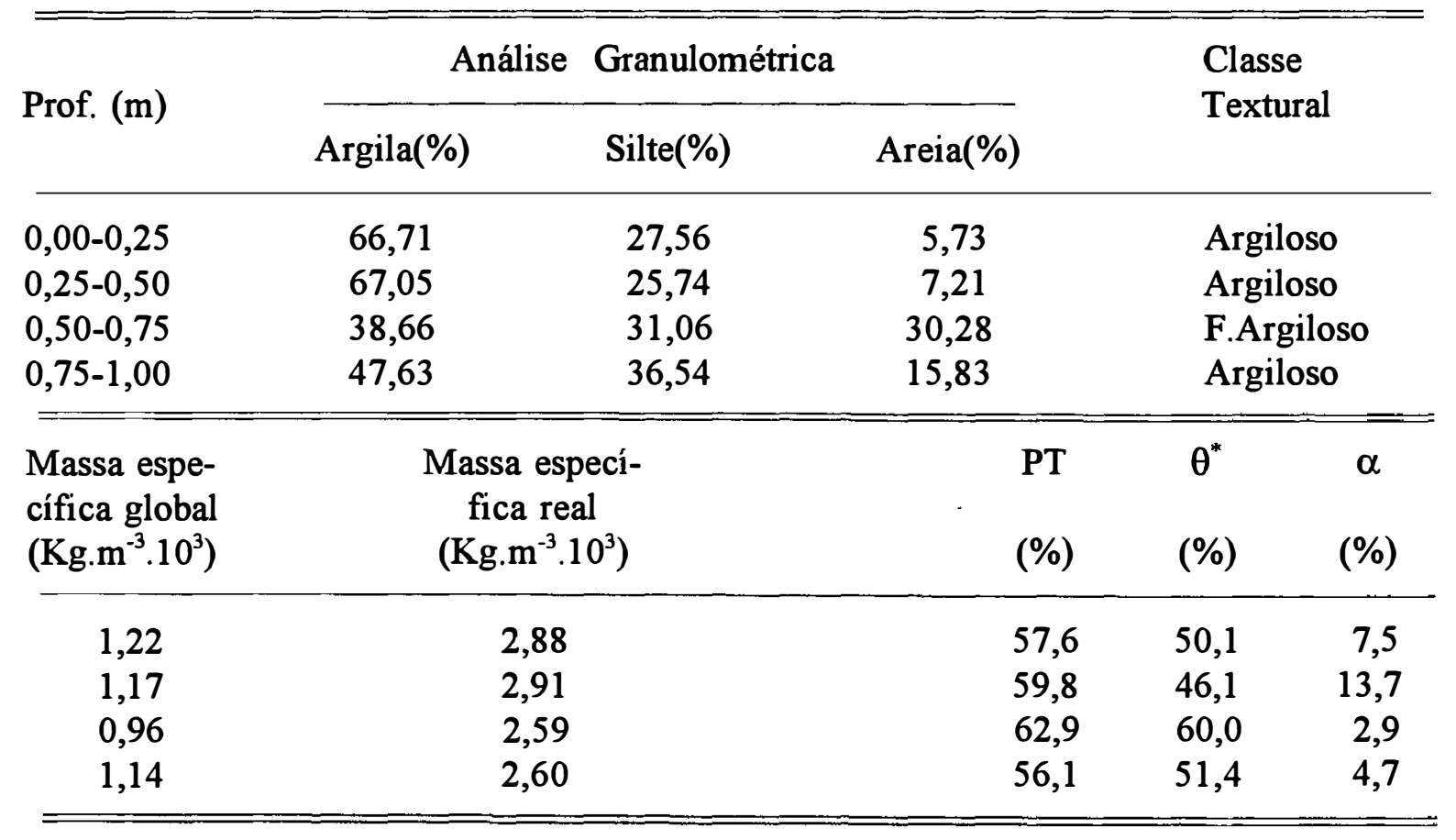

$\theta^{*}$ - umidade volumétrica à tensão de $3 \times 10^{4} \mathrm{~Pa}$;

$\alpha$ - porosidade efetiva ou drenável

PT - porosidade total

${ }^{3}$ Análises realizadas no Laboratório de Física de Solos do Departamento de Engenharia Rural da ESALQ/USP. 


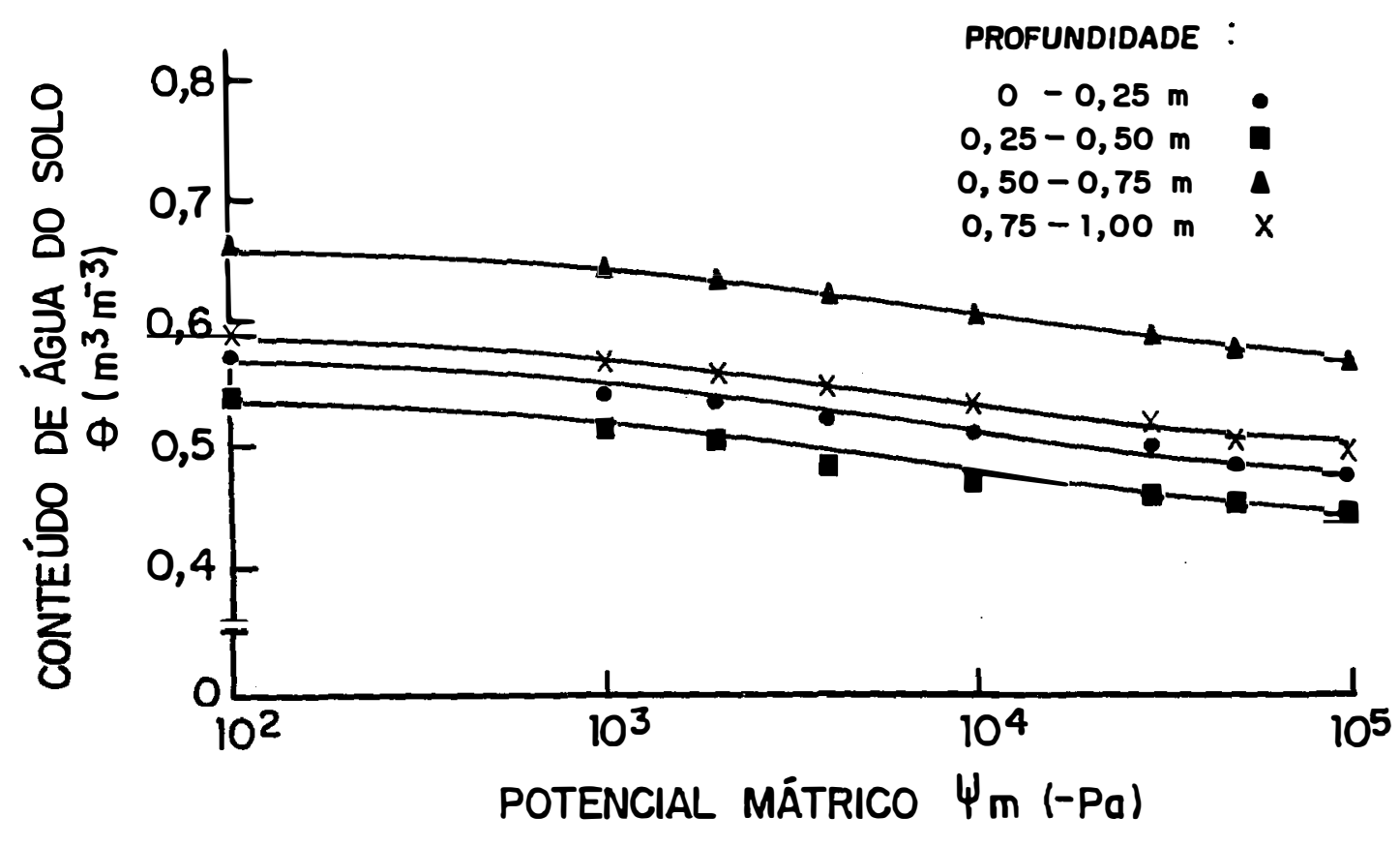

Figura 2 - Curvas caracteristicas de umidade do solo da área experimental 
Quadro 3. Características químicas do solo da área experimental ${ }^{4}$

\begin{tabular}{|c|c|c|c|c|c|c|c|}
\hline \multicolumn{2}{|c|}{ Prof. (m) } & & \multicolumn{2}{|l|}{ pH em água } & \multicolumn{2}{|c|}{ M.O. (\%) } & $P(p p m)$ \\
\hline \multicolumn{3}{|c|}{$0,00-0,25$} & \multicolumn{2}{|l|}{6,4} & \multicolumn{2}{|l|}{2,8} & 43 \\
\hline \multicolumn{3}{|c|}{$0,25-0,50$} & \multicolumn{2}{|l|}{7,2} & \multicolumn{2}{|l|}{2,3} & 41 \\
\hline \multicolumn{3}{|c|}{$0,50-0,75$} & \multicolumn{2}{|l|}{5,9} & \multicolumn{2}{|l|}{6,5} & 62 \\
\hline $0,75-1$ & 00 & & \multicolumn{2}{|l|}{6,5} & \multicolumn{2}{|l|}{2,3} & 13 \\
\hline \multicolumn{3}{|c|}{ Complexo sortivo } & \multicolumn{4}{|c|}{$\mathrm{mE} / 100 \mathrm{~g}$ de solo } & $100 \mathrm{~S} / \mathrm{T}$ \\
\hline $\mathrm{Ca}^{2+}$ & $\mathrm{Mg}^{2+}$ & $\mathrm{K}^{+}$ & SB & $\mathrm{H}^{+}+\mathrm{Al}^{3+}$ & $\mathrm{Al}^{3+}$ & СтC & \\
\hline 19,0 & 21,0 & 0,31 & 40,3 & 2,8 & 0,2 & 43,1 & 94,0 \\
\hline 32,0 & 24,0 & 0,24 & 56,2 & 1,3 & 0,1 & 57,5 & 98,0 \\
\hline 12,0 & 8,0 & 0,14 & 20,1 & 3,8 & 0,2 & 23,9 & 84,0 \\
\hline 13,0 & 8,0 & 0,10 & 21,1 & 1,8 & 0,0 & 22,9 & 92,0 \\
\hline
\end{tabular}

\subsubsection{Sistema de drenagem subtenânea}

$\mathrm{Na}$ área experimental, implantou-se um sistema de drenagem subterrânea, constituido de dezenove linhas de drenos laterais, locadas em direção perpendicular ao coletor, com comprimento de $45,0 \mathrm{~m}$ e espaçamento consecutivo de $10,0 \mathrm{~m}$, o qual permitiria a obtenção de espaçamentos com valores múltiplos ao adotado. A profundidade média de instalação foi de $1,00 \mathrm{~m}$ em relação ao terreno sistematizado, com gradiente de declive, no sentido do coletor, de $0,003 \mathrm{~m} / \mathrm{m}$, e no sentido transversal, de 0,002 $\mathrm{m} / \mathrm{m}$. No ponto de descarga dos drenos laterais, junto ao coletor, deixou-se uma folga de $0,40 \mathrm{~m}$.

${ }^{4}$ Análises realizadas no Laboratório de Análises de Solos do Departamento de Ciência do Solo da ESALQ/USP. 
Os drenos laterais foram construídos com tubos de drenagem corrugados flexíveis de PVC (DN 100), sendo utilizada como envelope de recobrimento dos drenos, uma manta de poliéster denominada bidim OP-30.

\subsubsection{Parcelas experimentais}

As parcelas experimentais, num total de dezoito, cujas dimensões eram de $9,0 \mathrm{~m} \times 5,0 \mathrm{~m}$, foram locadas na parte central, entre drenos laterais consecutivos, visando a coincidir com a maior elevação do lençol freático.

Os tratamentos avaliados consistiram em espaçamentos de drenos laterais a $10,0 \mathrm{~m}\left(\mathrm{~T}_{1}\right), 20,0 \mathrm{~m}\left(\mathrm{~T}_{2}\right)$ e $30,0 \mathrm{~m}\left(\mathrm{~T}_{3}\right)$. Dessa forma, no local de descarga dos drenos laterais, junto ao coletor, procedeu-se a uma obstrução, com a finalidade de obter espaçamentos de $20,0 \mathrm{~m}$ e $30,0 \mathrm{~m}$, conforme requerido pela pesquisa. As obstruções foram efetuadas através de tampões de PVC rígido (DN 100).

Instalaram-se duas fileiras de poços de observação, sendo cada uma constituída de dezenove poços, com a finalidade de se proceder à caracterização do comportamento do lençol freático, através de medidas de cargas hidráulicas em função do tempo, de mapas das curvas de nível do lençol freático e da descrição de sua forma entre drenos.

Os poços foram abertos com trado tipo holandês, de $0,05 \mathrm{~m}$ de diâmetro a profundidade variável. Para sua instalação, utilizaram-se tubos de PVC rígido, de $0,04 \mathrm{~m}$ de diâmetro, fendilhados com serra e envelopados com brita zero até a superfície. 
Após instalados, os poços ficaram com um comprimento uniforme de 0,30m acima da superfície do solo, fixados com uma base de cimento, nivelada à superfície do terreno, com cotas fixadas a partir de um nivelamento geométrico da área, para servir de referência de nível do lençol freático.

As fileiras de poços de observação foram distribuídas na área experimental transversalmente às linhas de drenos laterais. As fileiras $\mathrm{A}$ e $\mathrm{B}$ foram localizadas a $11,25 \mathrm{~m}$ e $33,75 \mathrm{~m}$, respectivamente, do local de deságue dos drenos. Os poços foram locados sobre as linhas de drenos e no ponto médio entre duas linhas, sendo a distribuição idêntica para as duas baterias. A Figura 3 mostra o croqui da área experimental.

\subsection{Leituras dos poços de observação e descargas dos drenos laterais}

Às leituras dos poços de observação e descargas dos drenos laterais procedia-se sempre que ocorresse uma recarga natural. Inicialmente, mediam-se as descargas dos drenos e, em seguida, efetuavam-se as leituras junto às duas fileiras de poços de observação. Esses dados eram coletados até o dia em que o lençol freático praticamente não apresentasse variação no nível, em relação ao dia anterior, sendo reiniciado logo após uma nova recarga. A disponibilidade desses dados permitiu fazer-se uma análise do funcionamento do sistema de drenagem subterrânea, através de estimativa da eficiência de rebaixamento do lençol freático. As descargas dos drenos laterais são mostradas no Quadro 2 do Apêndice. 


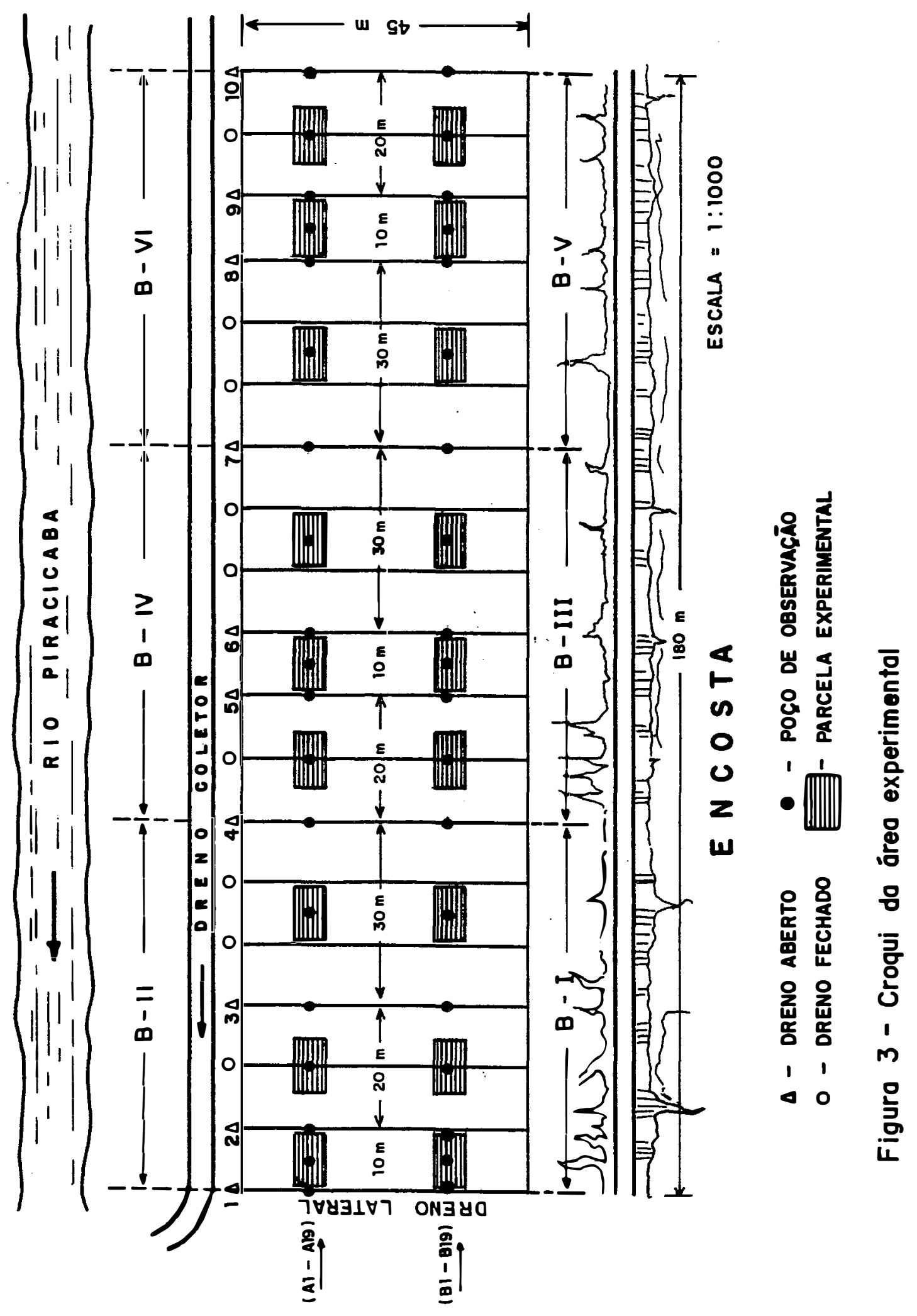




\subsection{Condutividade hidráulica do solo saturado}

Ao longo do experimento, realizaram-se testes de condutividade hidráulica do solo saturado $\left(\mathrm{K}_{\mathrm{o}}\right)$, utilizando-se o método do poço ou trado, tradicionalmente o mais usado em pesquisa de drenagem subterrânea. Os testes foram realizados na parte central entre os drenos laterais 1 e 2 , num total de cinco testes, com três repetições cada, a intervalos de 24 horas.

No cálculo de $\mathrm{K}_{\mathrm{o}}$, utilizou-se metodologia proposta por Ernst ${ }^{5}$ e detalhada por CRUCIANI (1989), condição em que a distância entre o fundo do poço e a camada impermeável é maior que a metade da distância entre o nível freático e o fundo do poço, conforme a expressão:

$$
K_{\mathrm{o}}=\frac{4000}{(H / I+20)(2-Y / H)} \frac{I \cdot \Delta Y}{Y \cdot \Delta t} . . .
$$

sendo:

$\mathrm{K}_{\mathrm{o}}$ - condutividade hidráulica do solo saturado, $L \cdot \mathrm{T}^{-1}$;

H - profundidade do poço, abaixo do nível freático, L;

Y - distância entre o nível freático e o ponto médio dos níveis de água no intervalo de tempo $\Delta t$, L;

r - raio do poço, $\mathrm{L}$;

$\Delta \mathrm{Y}$ - intervalo de altura no tempo $\Delta \mathrm{t}, \mathrm{L}$;

$\Delta t$ - intervalo de tempo entre duas leituras, $T$.

${ }^{5}$ ERNST, L.F. A new formula for the calculation of the permeability factor with the auger hole method. T.N.O. Groningen (traduzido do holandês por H. Bouwer, Ítaca, N. York, Cornell University), 1950. 
PIZARRO (1978) recomenda a correção da condutividade hidráulica para uma temperatura padrão de $20^{\circ} \mathrm{C}$, visto que, para diferentes condições de temperatura, ocorrem mudanças na viscosidade da água, acarretando, consequentemente, variações na condutividade hidráulica do solo. Os valores de $\mathrm{K}_{\mathrm{o}}$ foram corrigidos para a temperatura de $20^{\circ} \mathrm{C}$, utilizando-se a seguinte expressão:

$$
K_{0}\left(20^{\circ} \mathrm{C}\right)=\frac{\eta \cdot K_{0}}{\eta_{20}} \ldots . . . . .
$$

sendo:

$\mathrm{K}_{\mathrm{o}}$ - condutividade hidráulica do solo saturado à temperatura ambiente, L.T $^{-1}$; $\mathrm{K}_{\mathrm{o}}\left(20^{\circ} \mathrm{C}\right)$ - condutividade hidráulica do solo saturado a $20^{\circ} \mathrm{C}, \mathrm{L} \cdot \mathrm{T}^{-1}$; $\eta$ - viscosidade dinâmica da água à temperatura ambiente, $M \cdot L^{-1} \cdot T^{-1}$; $\eta_{20}$ - viscosidade dinâmica da água a $20^{\circ} \mathrm{C}, \mathrm{M}^{\mathrm{N}} \mathrm{L}^{-1} \cdot \mathrm{T}^{-1}$.

A condutividade hidráulica do solo saturado $\left(\mathrm{K}_{\mathrm{o}}\right)$, obtida com base nos respectivos testes, foi da ordem de $7,06 \times 10^{-6} \mathrm{~m} \cdot \mathrm{s}^{-1}$.

\subsection{Profundidade efetiva do sistema radicular}

A profundidade efetiva do sistema radicular apresenta-se como parâmetro de suma importância, em face da necessidade de melhor caracterizar os requerimentos de drenagem das culturas. Com efeito, a ausência dessa clareza constitui-se fator limitante da otimização na eficiência dos projetos. Na presente pesquisa, esse 
parâmetro foi obtido a partir da coleta aleatória em trinta plantas competitivas na área experimental, cujo valor médio foi igual a $0,20 \mathrm{~m}$.

$\mathrm{Na}$ coleta do material, realizou-se uma escavação cuidadosa ao redor da planta para não danificar seu sistema radicular, sendo ela retirada juntamente com um volume de solo(torrão), e, em seguida, levada para lavagem em água corrente. A Figura 4 mostra aspectos do sistema radicular da cultura.

\subsection{Flutuações do lençol freático}

As flutuações do lençol freático podem propiciar situações de estresse não só de excesso de água, como também de seca, e alternadamente, durante o ciclo de uma cultura. Embora sejam necessárias informações de tolerância das culturas tanto ao excesso, quanto ao déficit de água, essa pesquisa deu ênfase à tolerância ao excesso de água.

No presente trabalho, as leituras de profundidade do lençol freático, nos poços de observação, localizados no centro de cada parcela, foram concentradas entre o estádio de emergência dos estilo-estigmas, quando a cultura é acentuadamente dependente do clima, e o estádio correspondente ao início da formação de "dentes", de acordo com FANCELLI \& LIMA (1982). A idéia inicial de coletar dados em todo ciclo da cultura não foi possível, em decorrência de limitações de tempo no estabelecimento do experimento. 


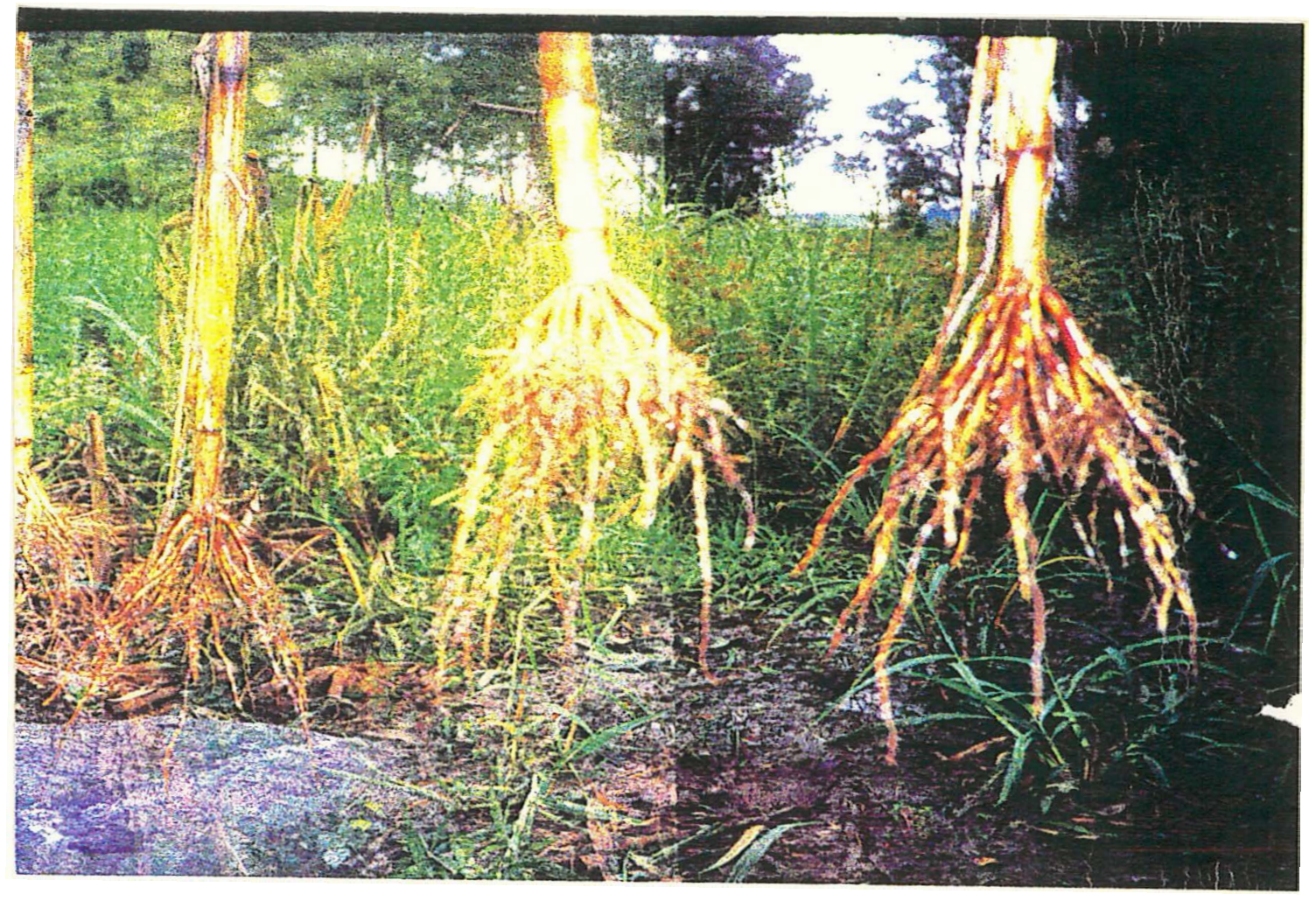

Figura 4 - Aspectos do sistema radicular da cultura 
Os dados de profundidade do lençol freático permitirão quantificar, para cada unidade experimental, o índice de estresse SEW, que representará a soma do valor excedente de água no solo, conhecido como a "soma do excesso de água", para avaliar o efeito, sobre a produtividade, da ocorrência do lençol freático na zona radicular da cultura. Tendo em vista a profundidade do sistema radicular definido anteriormente no ítem 3.6, adotar-se-á na presente pesquisa, o índice de estresse $\mathrm{SEW}_{20}$. No cálculo, utilizar-se-á a seguinte equação:

$$
S E W_{20}=\sum_{i=1}^{n}\left(20-x_{i}\right) \cdot . . . . . . .
$$

sendo:

$$
\begin{aligned}
& x_{i} \text { - profundidade do lençol freático abaixo da superfície do solo no dia } \mathrm{i} \text {, em cm; } \\
& \text { n - número de dias na estação de crescimento. }
\end{aligned}
$$

0 método estabelece o critério de que números negativos dentro da somatória sejam negligenciados, ou seja, só serão computados valores de $\mathrm{x}_{\mathrm{j}}$ menores que 20.

As produtividades absolutas do milho foram convertidas para produtividades relativas, considerando-se a razão entre a produtividade medida para cada parcela e a produtividade potencial, sendo esta considerada como a produtividade mais alta. $\mathrm{Na}$ análise da dinâmica do lençol freático em relação ao rendimento da cultura, realizaramse análises de ajuste de equações relacionando produtividade relativa com profundidade 
média do lençol freático e produtividade relativa com $\mathrm{SEW}_{20}$. Um programa computacional para ajuste de equações em dados experimentais foi usado para encontrar-se o modelo que melhor se adaptasse. Três funções matemáticas(linear, exponencial e potencial) foram usadas para ajustar os dados.

\subsection{Condução da cultura no campo}

Instalado o sistema de drenagem subterrânea, procedeu-se ao preparo da área e, em seguida ao estabelecimento da cultura de milho. Utilizou-se a variedade Piranão VD2, de porte baixo, alta produtividade e boas características agronômicas, oriunda do Departamento de Genética da ESALQ e obtida por PATERNIANI (1973), pelo emprego do gene braquítico-2.

A semeadura, realizada no dia 06.11 .1992 , foi manual, com fileiras espaçadas $0,90 \mathrm{~m}$ entre si, em direção paralela aos drenos laterais. $\mathrm{Na}$ oportunidade, foi realizada adubação de fundação, com base na análise de fertilidade do solo, a qual sugeria a aplicação de $10 \mathrm{~kg} \cdot \mathrm{ha}^{-1}$ de $\mathrm{N}, 75 \mathrm{~kg} \cdot \mathrm{ha}^{-1}$ de $\mathrm{P}_{2} \mathrm{O}_{5}$ e $50 \mathrm{~kg} \cdot \mathrm{ha}^{-1}$ de $\mathrm{K}_{2} \mathrm{O}$.

No sétimo dia após a germinação, realizou-se o replantio, sendo o desbaste realizado quinze dias após essa operação. Adubação de cobertura foi efetuada quarenta dias após a germinação, à base de $80 \mathrm{~kg} \cdot \mathrm{ha}^{-1}$ de $\mathrm{N}$.

Aplicaram-se duas pulverizações de caráter preventivo contra a lagarta do cartucho(Spodoptera frugiperda), à base do inseticida Criolita(fluor aluminato de sódio), na dosagem de $9 \mathrm{Kg} \cdot \mathrm{ha}^{-1}$ de ingrediente ativo na formulação pó molhável. 
Durante todo o ciclo, a cultura foi mantida livre da concorrência de ervas daninhas, realizando-se, quando necessário, capinas manuais. A Figura 5 mostra uma vista geral do experimento.

No dia 19.03.1993, realizou-se a colheita - aleatoriamente, trinta plantas competitivas, da área útil de cada parcela experimental, formaram a base da determinação dos parâmetros de produção da cultura. A bordadura era formada pelas duas últimas fileiras de plantas localizadas nas laterais das parcelas e as quatro primeiras plantas na extremidade de cada fileira.

Após a colheita das parcelas separadamente, as espigas eram postas a secar à sombra, em seguida, pesadas e imediatamente debulhadas, anotando-se o peso dos grãos e separando uma amostra de $0,25 \mathrm{~kg}$ de milho para determinação do teor de umidade, utilizando-se, para isso, o aparelho "Steinlite - Eletronic Moisture Tester" modelo RCSample Wt. A seguir, foram feitas correções em função da umidade, utilizando-se a seguinte fórmula:

$$
P C(15,5 \%)=\frac{P C(1-U)}{(1-0,155)} ; . . . . . \cdot
$$

sendo:

PC(15,5\%): peso seco corrigido para $15,5 \%$ de umidade;

PC: peso de campo observado;

U: umidade observada;

(1 - 0,155): expressa a matéria seca a umidade de 15,5\%. 


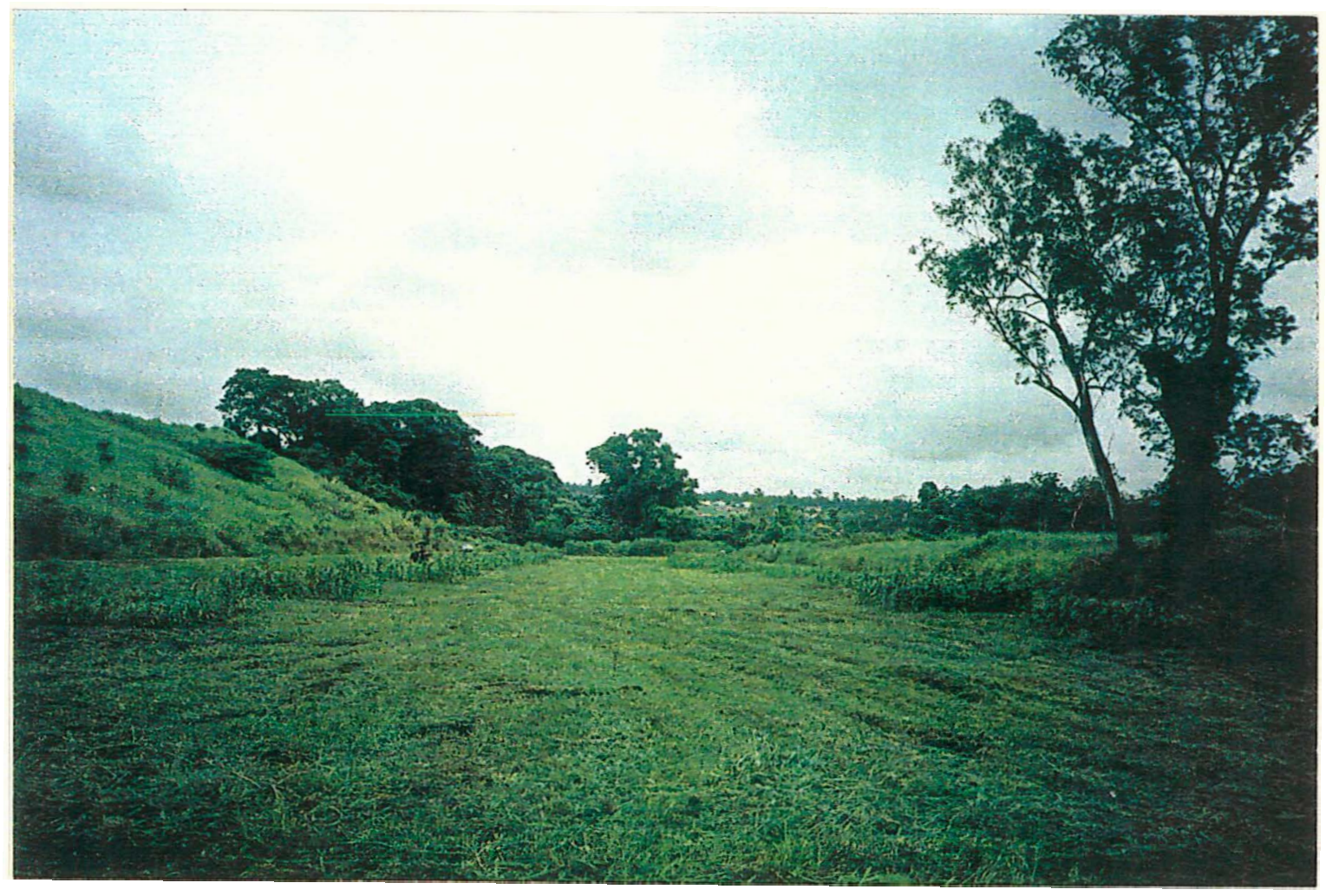

Figura 5 - Vista geral da cultura estabelecida no campo 


\subsection{Delineamento experimental}

$$
\text { O delineamento estatístico realizou-se em blocos completos }
$$

casualizados, constando de três tratamentos e seis blocos. De acordo com GOMES (1990), o modelo matemático associado a esse delineamento é:

$$
X_{i j}=m+t_{i}+b_{j}+e_{i j} ;
$$

sendo:

$\mathrm{X}_{\mathrm{ij}}$ : observação do tratamento i na repetição $\mathrm{j}$;

m : média geral;

$t_{i}$ : efeito do i-ésimo tratamento na variável dependente;

$b_{j}$ : efeito do j-ésimo bloco na variável dependente;

$\mathrm{e}_{\mathrm{ij}}$ : erro aleatório atribuido à observação $\mathrm{X}_{\mathrm{ij}}$.

As variáveis utilizadas para testar a influência dos tratamentos consistiram dos seguintes caracteres de produção da cultura do milho:

- Altura de planta: obtida medindo-se a distância da superfície do solo até a inserção da última folha;

- Peso de 100 grãos: determinado a partir de uma amostra de 100 grãos tomada aleatoriamente, do total debulhado de cada parcela;

- Peso médio das espigas: valor obtido por divisão do peso total das espigas pelo número delas, em cada unidade experimental; 
- Peso de grãos por espiga: determinado pela diferença entre o peso das espigas e o peso dos sabugos;

- Produtividade: obtida com base no peso de grãos por espiga e transformada em kg.ha ${ }^{-1}$.

As análises estatísticas foram realizadas segundo o esquema de blocos completos casualizados, de acordo com os critérios estabelecidos pela estatística experimental (GOMES, 1990). Para análise, utilizou-se o programa de computação SANEST (Sistema de Análise Estatística). Procedeu-se a uma análise de variância individual para cada um dos parâmetros de produção, sendo as médias comparadas pelo teste de Tukey, aos níveis de $5 \%$ e $1 \%$ de probabilidade.

$\mathrm{Na}$ análise de variância, os tratamentos foram comparados pelo teste F, considerando-se um nível mínimo de significância de $5 \%$ de probabilidade. Além da análise de variância, os caracteres de produção foram estudados através de análise de correlação simples, sendo aplicado o teste t para cada uma das correlações. 


\section{RESULTADOS E DISCUSSĀO}

\subsection{Recarga do lençol freático}

A recarga do lençol freático foi promovida exclusivamente por precipitações naturais. Durante o ciclo da cultura, a precipitação acumulada atingiu 747,3 $\mathrm{mm}$, com totais mensais sempre um pouco acima da precipitação dependente, a $75 \%$ de probabilidade, ou seja, da quantidade mínima de precipitação que se esperava ocorrer, com uma probabilidade de 75\% (MARQUES Jr. et al., 1994). Verifica-se, portanto, que, hidrologicamente, o período não foi atípico, não se constituindo, por conseguinte, em fator limitante para os objetivos da presente pesquisa.

A Figura 6 mostra a distribuição das precipitações ocorridas durante o ciclo da cultura. 


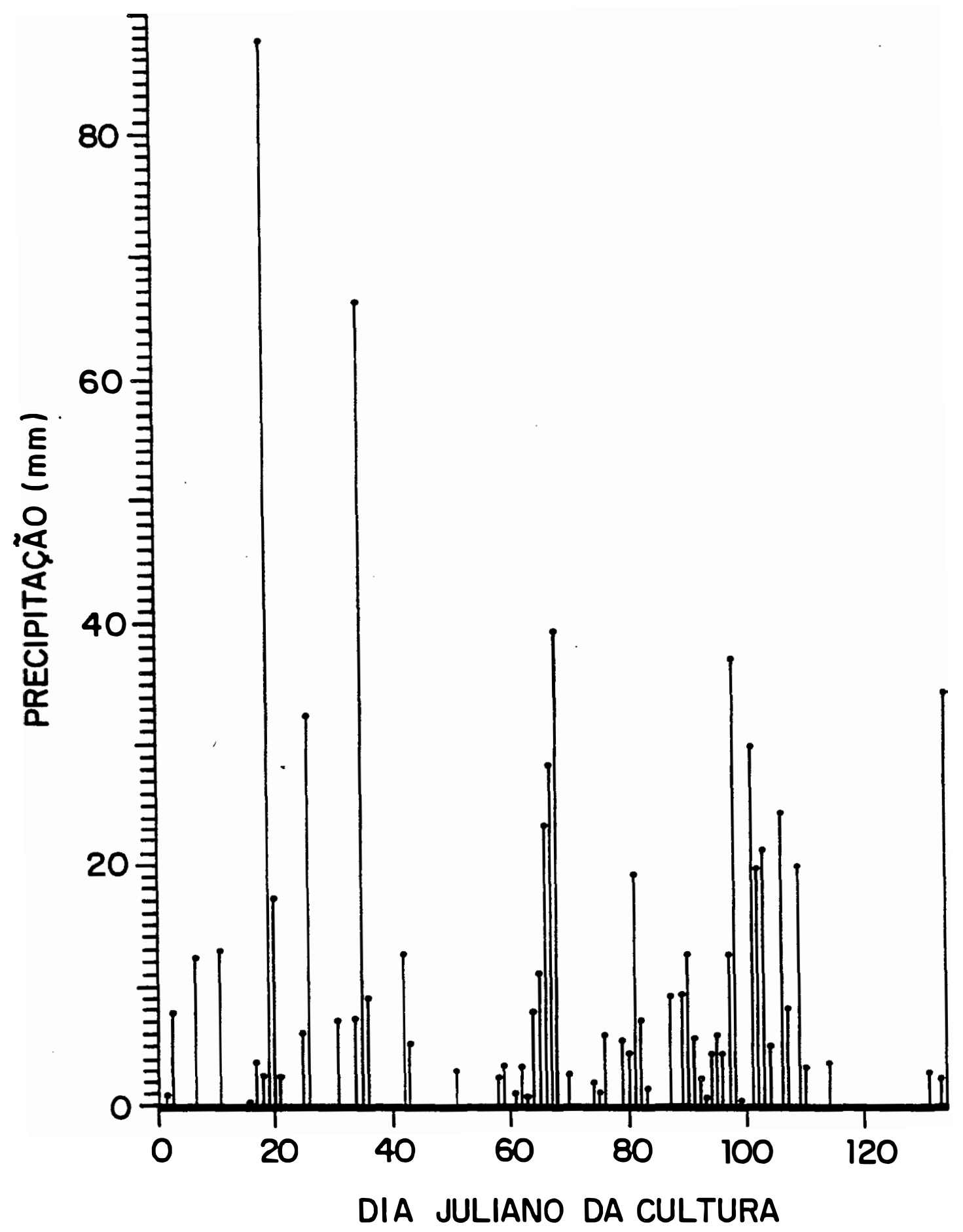

Figura 6 - Distribuição das precipitações no ciclo da cultura 


\subsection{Análise dos caracteres de produção}

O Quadro 4 mostra os resultados referentes às médias dos caracteres de produção do milho, os quais constituíram as variáveis utilizadas para testar a influência dos tratamentos. Nos Quadros 5 e 6, constam, respectivamente, os resumos das análises de variância para altura de planta, peso de 100 grãos, peso médio das espigas, peso de grãos por espiga e produtividade.

Nesses quadros constam, também, as médias e os coeficientes de variação para cada carácter de produção, além do Teste de Tukey para médias de tratamentos.

De acordo com PIMENTEL GOMES (1990), em se tratando de ensaios agrícolas em condições de campo, podem ser considerados como baixos os coefícientes de variação inferiores a $10 \%$; médios, quando de 10 a $20 \%$; altos, quando de $20 \%$ a $30 \%$; muito altos, quando superiores a $30 \%$. Os coefícientes de variação para os caracteres estudados apresentaram uma amplitude de 2,56 a 14,35\%, indicando, dessa forma, uma boa precisão experimental.

Observa-se, com base nos resultados das análises estatísticas, que, embora os caracteres de produção tenham apresentado uma tendência diferenciada em relação aos tratamentos, tais discrepâncias não foram estatisticamente significativas aos níveis de 5 e 1\%, exceção à variável peso de 100 grãos. 
Quadro 4. Médias dos caracteres de produção do milho em função dos tratamentos aplicados

\section{BLOCOS}

TRAT.

$\begin{array}{lllllll}\text { I } & \text { II } & \text { III } & \text { IV } & \text { V } & \text { VI }\end{array}$

\begin{tabular}{|c|c|c|c|c|c|c|}
\hline \multirow[b]{2}{*}{$\mathrm{T}_{1}$} & \multicolumn{6}{|c|}{ ALTURA DE PLANTA (m) } \\
\hline & 1,31 & 1,23 & 1,26 & 1,14 & 1,22 & 1,35 \\
\hline $\mathrm{T}_{2}$ & 1,31 & 1,19 & 1,31 & 1,23 & 1,20 & 1,21 \\
\hline \multirow[t]{2}{*}{$\mathrm{T}_{3}$} & 1,30 & 1,25 & 1,24 & 1,13 & 1,26 & 1,16 \\
\hline & \multicolumn{6}{|c|}{ PESO DE 100 GRÃOS (g) } \\
\hline$T_{1}$ & 31,62 & 32,79 & 32,84 & 31,04 & 28,96 & 30,02 \\
\hline$T_{2}$ & 31,40 & 30,31 & 31,23 & 28,71 & 27,32 & 28,26 \\
\hline \multirow[t]{2}{*}{$\mathrm{T}_{3}$} & 30,72 & 30,04 & 29,74 & 29,15 & 27,38 & 25,60 \\
\hline & \multicolumn{6}{|c|}{ PESO MÉDIO DAS ESPIGAS (g) } \\
\hline $\mathrm{T}_{1}$ & 125,2 & 125,2 & 137,2 & 124,0 & 101,4 & 106,8 \\
\hline $\mathrm{T}_{2}$ & 127,6 & 119,0 & 127,2 & 124,0 & 83,0 & 73,7 \\
\hline \multirow[t]{2}{*}{$\mathrm{T}_{3}$} & 136,6 & 135,6 & 106,5 & 82,4 & 101,0 & 73,7 \\
\hline & \multicolumn{6}{|c|}{ PESO DE GRÃOS POR ESPIGA (g) } \\
\hline $\mathrm{T}_{1}$ & 104,4 & 107,3 & 115,4 & 79,5 & 84,5 & 90,5 \\
\hline $\mathrm{T}_{2}$ & 109,3 & 100,8 & 106,6 & 103,2 & 69,5 & 65,3 \\
\hline \multirow[t]{2}{*}{$\mathrm{T}_{3}$} & 115,5 & 114,0 & 89,3 & 67,8 & 84,0 & 61,7 \\
\hline & \multicolumn{6}{|c|}{ PRODUTIVIDADE (Kg.ha' $\left.{ }^{-1}\right)$} \\
\hline $\mathrm{T}_{1}$ & 5220,0 & 5740,6 & 6000,8 & 3975,0 & 4267,3 & 4434,5 \\
\hline $\mathrm{T}_{2}$ & 5465,0 & 5292,0 & 5489,9 & 5366,4 & 3405,5 & 3199,7 \\
\hline $\mathrm{T}_{3}$ & 5775,0 & 5814,0 & 4465,0 & 3390,0 & 4284,0 & 3085,0 \\
\hline
\end{tabular}


Quadro 5. Análise de variância dos caracteres de produção

$$
\text { Q.M. }
$$

F.V. $\quad$ G.L.

$$
\text { Alt.Pl. P.100G P.Esp. P.G/E Prod. }
$$

$\begin{array}{lcccccc}\text { Trat. } & 2 & 0,0012^{\text {ns }} & 9,3416^{* *} & 113,7414^{\text {ns }} & 101,5477^{\text {ns }} & 332574,59^{\text {ns }} \\ \text { Res. } & 10 & 0,0029 & 0,5858 & 220,9562 & 158,6794 & 455870,84\end{array}$

ns : não significativo pelo teste $\mathrm{F}$ ao nível de $5 \%$

** : significativo pelo teste $\mathrm{F}$ ao nível de $1 \%$.

Quadro 6. Teste de Tukey para médias de tratamentos

$\begin{array}{llll}\text { Alt.Pl. P.100G P.Esp. } & \text { P.G/E }\end{array}$

Trat. Média Média Média Média Média

\begin{tabular}{llllll} 
T.1 & $1,252 \mathrm{a}$ & $31,212 \mathrm{a}$ & $114,967 \mathrm{a}$ & $96,933 \mathrm{a}$ & $4939,700 \mathrm{a}$ \\
T.2 & $1,242 \mathrm{a}$ & $29,538 \mathrm{~b}$ & $109,900 \mathrm{a}$ & $92,450 \mathrm{a}$ & $4703,083 \mathrm{a}$ \\
T.3 & $1,223 \mathrm{a}$ & $28,772 \mathrm{~b}$ & $106,300 \mathrm{a}$ & $88,717 \mathrm{a}$ & $4468,833 \mathrm{a}$ \\
\hline
\end{tabular}

Médias seguidas por letras distintas, nas colunas, diferem entre si pelo teste de Tukey, nível de significância de $5 \%$. 


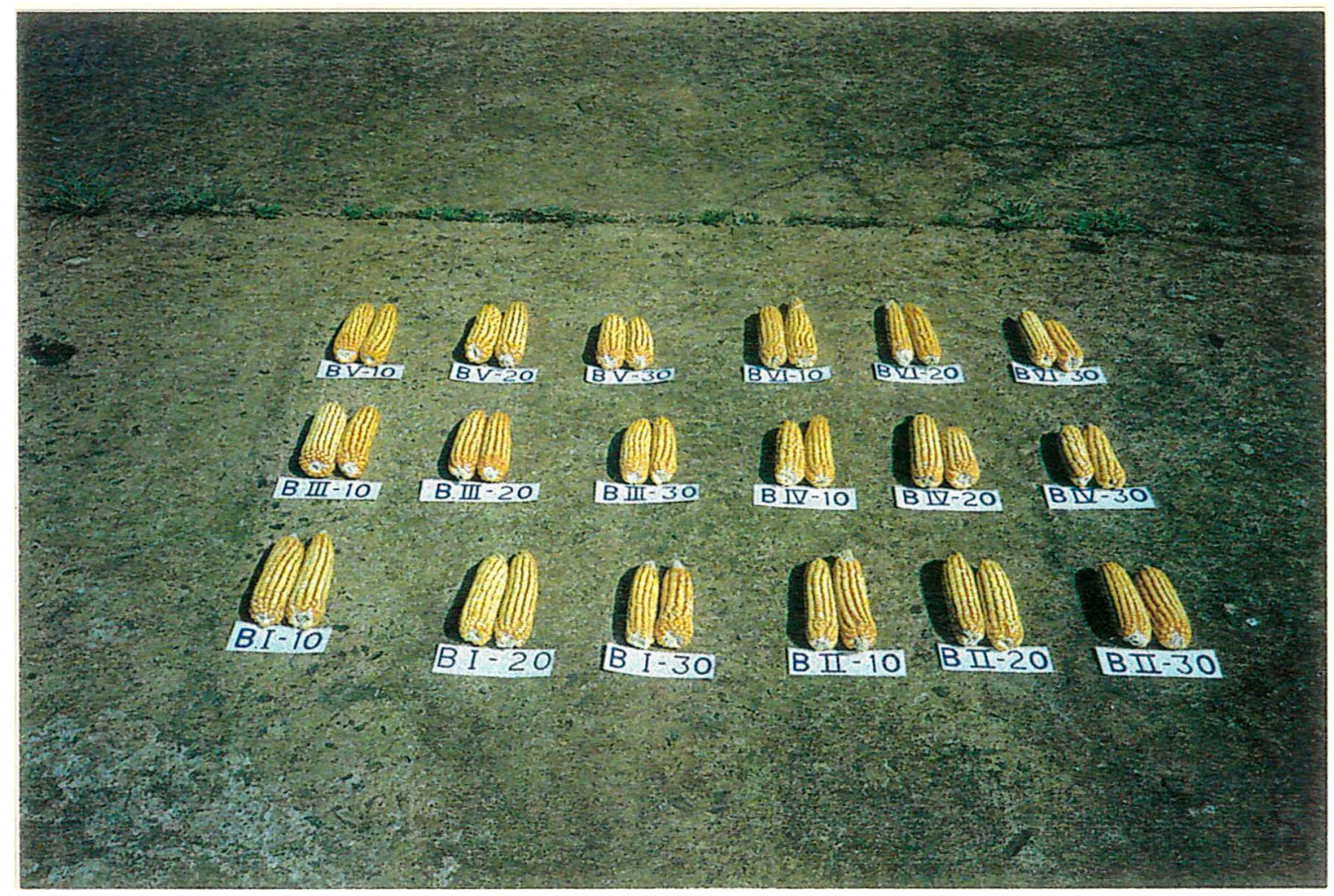

Figura 7 - Aspectos das amostras de espigas em função dos tratamentos aplicados 
No Quadro 7, são apresentados os resultados referentes à análise de correlação linear para os caracteres de produção analisados. Tomando-se como base a produtividade, que se constitui no principal carácter de produção, verifica-se uma correlação positiva (significativa pelo teste $t$ ao nível de $1 \%$ ) com todos os outros caracteres analisados.

Quadro 7. Coeficientes de correlação simples entre os caracteres de produção

\begin{tabular}{lll}
$\mathrm{X}_{1}$ e $\mathrm{X}_{2}=0,4113$ & $\mathrm{X}_{1}$ e $\mathrm{X}_{3}=0,6320$ & $\mathrm{X}_{1}$ e $\mathrm{X}_{4}=0,6415$ \\
Valor $\mathrm{t}=1,8048^{\text {ns }}$ & Valor $\mathrm{t}=3,2621^{* *}$ & Valor $\mathrm{t}=3,3451^{* *}$ \\
\hline $\begin{array}{l}\mathrm{X}_{1} \text { e } \mathrm{X}_{5}=0,5875 \\
\text { Valor } \mathrm{t}=2,9040^{* *}\end{array}$ & $\begin{array}{l}\mathrm{X}_{2} \text { e } \mathrm{X}_{3}=0,7539 \\
\text { Valor } \mathrm{t}=4,5904^{* *}\end{array}$ & $\begin{array}{l}\mathrm{X}_{2} \text { e } \mathrm{X}_{4}=0,7618 \\
\text { Valor } \mathrm{t}=4,7042^{* *}\end{array}$ \\
\hline $\mathrm{X}_{2}$ e $\mathrm{X}_{5}=0,7627$ & $\mathrm{X}_{3}$ e $\mathrm{X}_{4}=0,9989$ & $\mathrm{X}_{3}$ e $\mathrm{X}_{5}=0,9935$ \\
Valor $\mathrm{t}=4,7176^{* *}$ & Valor $\mathrm{t}=85,3414^{* * *}$ & Valor $\mathrm{t}=34,9910^{* *}$ \\
\hline $\mathrm{X}_{4}$ e $\mathrm{X}_{5}=0,9942$ & & \\
Valor $\mathrm{t}=36,9203^{* *}$ & \\
\hline
\end{tabular}

ns : não significativo pelo teste $t$ ao nível de $5 \%$

** : significativo pelo teste $\mathrm{t}$ ao nível de $1 \%$.

sendo:

$\mathrm{X}_{1}$ : altura de planta

$\mathrm{X}_{2}$ : peso de 100 grãos

$\mathrm{X}_{3}$ : peso médio das espigas

$\mathrm{X}_{4}$ : peso de grãos por espiga

$\mathrm{X}_{5}$ : produtividade 
Resultados semelhantes são relatados por PEREIRA (1990). Dessa forma, um aumento em qualquer um desses caracteres acarretará aumento na produtividade, dentro das condições desse estudo. Os resultados demonstram, também, que os demais caracteres de produção se correlacionaram significativamente entre si. Esses resultados podem ser explicados, com base na interdependência existente entre esses caracteres de produção.

O porte baixo dessa variedade de milho foi obtido pelo emprego do gene recessivo braquítico-2, o qual não interfere na produtividade da cultura. Características de produtividade, estão relacionadas à capacidade de fotossintetização, a qual depende das condições do meio. Daí a explicação para o fato das correlações entre altura de planta e peso de 100 grãos, terem sido não significativas pelo teste $t$ ao nível de $5 \%$.

\subsection{Avaliação econômica do sistema de drenagem}

Os custos de implantação correspondentes aos investimentos de 1,0 ha de drenagem subterrânea, em função do espaçamento, são mostrados no Quadro 8. Dentre outros, consultou-se PREÇOS AGRÍCOLAS (1994). Tais custos correspondem aos valores dos investimentos necessários para a instalação completa do sistema de drenagem, não se considerando possíveis custos iniciais de saneamento e/ou sistematização. Na avaliação econômica, estimou-se a vida útil do sistema de drenagem como igual a 30 anos, de acordo com recomendações da FAO (1986), e uma captação de 
Quadro 8. Custos de implantação de 1,0 ha de drenagem subterrânea em função do espaçamento

\begin{tabular}{|c|c|c|c|c|}
\hline \multirow[b]{2}{*}{ Ítem Dreno lateral $(10,0 \mathrm{~m})$} & \multicolumn{4}{|c|}{ Preço (US\$) } \\
\hline & Unid. & Quant. & Unit. & Total \\
\hline $\begin{array}{l}\text { 01. Tubos de drenagem } \\
\text { 02. Envelope manta poliéster } \\
\text { 03. Escavação mec. valas } \\
\text { 04. Acabamento manual valas } \\
\text { 05. Levantamento altimétrico } \\
\text { 06. Amarrio manta poliéster } \\
\text { 07. Aterro mec. de valas }\end{array}$ & $\begin{array}{c}\mathrm{m} \\
\mathrm{m}^{2} \\
\mathrm{~m}^{3} \\
\mathrm{~h} / \mathrm{d} \\
\mathrm{d} \\
\mathrm{h} / \mathrm{d} \\
\mathrm{m}^{3}\end{array}$ & $\begin{array}{r}1000 \\
500 \\
500 \\
6 \\
2 \\
2,5 \\
350 \\
\end{array}$ & $\begin{array}{r}2.70 \\
1.61 \\
2.90 \\
2.93 \\
10.50 \\
2.93 \\
1.92 \\
\end{array}$ & $\begin{array}{r}2,700.00 \\
805.00 \\
1,450.00 \\
17.58 \\
21.00 \\
7.33 \\
672.00 \\
\end{array}$ \\
\hline Total & & & & $5,672.91$ \\
\hline Ítem Dreno lateral $(20,0 \mathrm{~m})$ & Unid. & Quant. & Unit. & Total \\
\hline 01. Tubos de drenagem & $\mathbf{m}$. & 500 & 2.70 & $1,350.00$ \\
\hline $\begin{array}{l}\text { 02. Envelope manta poliéster } \\
\text { 03. Escavação mec. valas } \\
\text { 04. Acabamento manual valas } \\
\text { 05. Levantamento altimétrico } \\
\text { 06. Amarrio manta poliéster } \\
07 \text {. Aterro mec. de valas }\end{array}$ & $\begin{array}{c}\mathrm{m}^{2} \\
\mathrm{~m}^{3} \\
\mathrm{~h} / \mathrm{d} \\
\mathrm{d} \\
\mathrm{h} / \mathrm{d} \\
\mathrm{m}^{3}\end{array}$ & $\begin{array}{r}250 \\
250 \\
3 \\
1,5 \\
1,5 \\
175 \\
\end{array}$ & $\begin{array}{r}1.61 \\
2.90 \\
2.93 \\
10.50 \\
2.93 \\
1.92 \\
\end{array}$ & $\begin{array}{r}402.50 \\
725.00 \\
8.79 \\
15.75 \\
4.40 \\
336.00 \\
\end{array}$ \\
\hline Total & & & & $2,842.44$ \\
\hline Ítem Dreno lateral $(30,0 \mathrm{~m})$ & Unid. & Quant. & Unid. & Total \\
\hline 01. Tubos de drenagem & m. & 333,4 & 2.70 & 900.07 \\
\hline $\begin{array}{l}\text { 02. Envelope manta poliéster } \\
03 \text {. Escavação mec. valas } \\
\text { 04. Acabamento manual valas } \\
\text { 05. Levantamento altimétrico } \\
\text { 06. Amarrio manta poliéster } \\
\text { 07. Aterro mec. de valas }\end{array}$ & $\begin{array}{c}\mathrm{m}^{2} \\
\mathrm{~m}^{3} \\
\mathrm{~h} / \mathrm{d} \\
\mathrm{d} \\
\mathrm{h} / \mathrm{d} \\
\mathrm{m}^{3}\end{array}$ & $\begin{array}{r}166,7 \\
166,7 \\
2,0 \\
1,0 \\
1,0 \\
116,7 \\
\end{array}$ & $\begin{array}{r}1.61 \\
2.90 \\
2.93 \\
10,50 \\
2.93 \\
1.92 \\
\end{array}$ & $\begin{array}{r}268.39 \\
483.43 \\
5.86 \\
10.50 \\
2.93 \\
224.06 \\
\end{array}$ \\
\hline Total & & & & $1,895.24$ \\
\hline
\end{tabular}


dinheiro necessário ao investimento a uma taxa de $12 \%$ ao ano. De acordo com HOFFMANN et al. (1992), quando se considera que as amortizações rendem juros, pode-se calcular uma anuidade que engloba os custos de amortização e juros do bem de capital. No presente trabalho, o valor final ou residual do sistema foi considerado igual a zero.

O fator de recuperação do capital (FRC) foi calculado conforme a equação:

$$
F R C=\frac{i(1+i)^{n}}{(1+i)^{n}-1} \cdot \ldots \cdot . . .
$$

sendo:

i - taxa real anual de juros, em decimal;

$\mathrm{n}$ - vida útil do sistema de drenagem, em anos.

A anuidade, que diz respeito à capacidade de pagamento a ser efetuada em $\mathbf{n}$ anos, para amortização do investimento, corresponde ao produto entre o fator de recuperação do capital e o custo do investimento inicial.

Com relação aos custos variáveis (manutenção e operação do sistema), para as condições do presente trabalho, não existiram custos com operação, tendo em vista o sistema operar com saída por gravidade. Já os custos médios anuais de manutenção foram estimados com base em recomendações da FAO(1986), e são da ordem de 4 a 10 dólares por hectare. Dessa forma, os custos variáveis não constaram da presente análise. Na hipótese da existência de um sistema de saída por bombeamento, os custos variáveis assumiriam papel relevante. 
O Quadro 9 mostra os preços dos elementos econômicos em 1,0 ha de drenagem subterrânea, obtidos nos diferentes espaçamentos de drenos laterais.

A estimativa do custo operacional e a exigência física de fatores de produção para a exploração de 1,0 ha da cultura de milho foi de US\$101.19, conforme o "custo operacional total", estimado por MELLO et al. (1986). De acordo com HOFFMANN et al. (1992), o custo operacional total difere do custo total apenas por não incluir os juros sobre o capital empatado e uma possível remuneração do empresário.

O Quadro 10 apresenta a renda bruta da cultura de milho em função da produtividade, obtida nos diferentes espaçamentos de drenos laterais. Já o Quadro 11, os dados econômicos para 1 ha de drenagem subterrânea nos diferentes espaçamentos de drenos laterais, considerando-se que o sistema de drenagem é utilizado para produzir duas safras de milho por ano. Para o cálculo da renda líquida anual, tem-se:

$$
R L=R B * 2-(C F+C O C * 2) \cdot \cdot \cdot \cdot \cdot \cdot
$$

sendo:

RB - renda bruta da cultura para uma safra(US\$/ha);

CF - custos fixos anuais(US\$/ha);

COC- custo operacional da cultura para uma safra(US\$/ha). 
Quadro 9. Elementos econômicos em 1,0 ha de drenagem

Espaçamento de drenos laterais

DL.10m DL. $20 \mathrm{~m} \quad$ DL. $30 \mathrm{~m}$

Investimento inicial (US\$)

Fator de rec. do capital

Anuidade (US\$)

Amortização investimento (anos)

$\begin{array}{ccc}5,672.91 & 2,842.44 & 1,895.24 \\ 0,1241 & 0,1241 & 0,124 \\ 704.01 & 352.75 & 235.2 \\ 30,00 & 30,00 & 30,0\end{array}$

Quadro 10. Renda bruta da cultura de milho em 1,0 ha.

\begin{tabular}{llll}
\hline & & \multicolumn{2}{c}{ Preço (US\$) } \\
\cline { 3 - 4 } Espaçamento(m) & Quant.prod. (kg) & Unit. & Total \\
& & & \\
\hline & & & \\
10,00 & $4.939,70$ & 0.13 & 642.20 \\
20,00 & $4.703,10$ & 0.13 & 611.40 \\
30,00 & $4.468,80$ & 0.13 & 580.94 \\
& & & \\
\hline
\end{tabular}

Quadro 11. Dados econômicos para 1 ha de drenagem em função do espaçamento de drenos laterais(*)

Espaçamento de drenos

$10,0 \mathrm{~m} \quad 20,0 \mathrm{~m} \quad 30,0 \mathrm{~m}$

\begin{tabular}{lrrr}
\hline Renda bruta(US\$/ano) & $1,284.40$ & $1,222.80$ & $1,161.88$ \\
Custos fixos(US\$/ano) & 704.01 & 352.75 & 235.20 \\
Custo oper. cult.(US\$/ano) & 202.38 & 202.38 & 202.38 \\
Renda líquida(US\$/ano) & 378.01 & 667.67 & 724.30 \\
\hline
\end{tabular}

* Cultura estabelecida - milho 
O valor da renda líquida constitui, portanto, o saldo ou resíduo de renda que se destina a remunerar a terra e o empresário. Esses resultados mostram que, dentre os tratamentos testados nas condições da presente pesquisa, o espaçamento de drenos laterais paralelos e equidistantes a 30,0m apresentou-se como a melhor alternativa econômica.

\subsection{Efeito do lençol freático no rendimento da cultura}

O espaçamento de drenos, por si só, não traz a lume o comportamento dinâmico do lençol freático, que, em última análise, traduz as condições de estresse de umidade e seca a que a cultura foi submetida.

Tomando-se como base que cada várzea possui características que lhe são peculiares, e dadas as condições de heterogeneidade que lhe são específicas, depreende-se a necessidade de um estudo com base no rendimento da cultura, a partir de dados diários do comportamento do lençol freático. $\mathrm{Na}$ presente pesquisa, utilizaram-se dados de profundidade do lençol freático entre $070^{\circ}$ e $113^{\circ}$ dia do ciclo da cultura.

O Quadro 3 do Apêndice mostra o tipo de tabulação de dados das leituras dos poços de observação, relativa ao dia 15.01 .1993 . O resumo das leituras de profundidades do lençol freático, para cada parcela experimental referente ao período estudado, é mostrado no Quadro 4 do Apêndice. 
Os dados referentes às variáveis para análise do ajuste de equações são apresentados no Quadro 12. Para oferecer uma visualização do comportamento das variáveis em análise, as Figuras 8 e 9 mostram, respectivamente, a dispersão dos pontos observados entre produtividade relativa, em função da profundidade média do lençol freático, e produtividade relativa em função de $\mathrm{SEW}_{20}$.

Com base na dispersão dos dados, não se visualiza a priori uma função matemática que expresse uma relação natural entre as variáveis. No intuito de encontrar uma função que descrevesse adequadamente esses dados, optou-se por três modelos comumente utilizados nesse tipo de análise. De acordo com PEREIRA \& ARRUDA (1987), muitas vezes necessita-se apenas de uma função que descreva os dados experimentais e não da melhor função que se possa ajustar àqueles dados. Portanto, o importante é a função e não o rigor e a sofisticação do método de ajuste. Conforme os autores, os métodos mais sofisticados são também mais sensíveis e nem sempre convergem para uma solução.

As equações de regressão da produtividade relativa, em função da profundidade média do lençol freático, acompanhadas das análises estatísticas referentes aos modelos estudados, são mostradas no Quadro 13. Complementando, o Quadro 14 apresenta as equações de regressão da produtividade relativa, em função do fator de estresse $\left(\mathrm{SEW}_{20}\right)$, e análises estatísticas dos respectivos modelos. 
Quadro 12. Dados para análise do ajuste de equações

\begin{tabular}{|c|c|c|c|}
\hline Bloco & Prof.LF(m) & $\mathrm{SEW}_{20}(\mathrm{~m} . \mathrm{dia})$ & Prod. relativa \\
\hline I. 10 & 0,108 & 2,40 & 0,87 \\
\hline I. 20 & 0,070 & 3,37 & 0,91 \\
\hline I.30 & 0,083 & 3,03 & 0,96 \\
\hline II.10 & 0,505 & 0,00 & 0,96 \\
\hline П.20 & 0,114 & 2,24 & 0,88 \\
\hline II.30 & 0,252 & 0,40 & 0,97 \\
\hline III.10 & 0,304 & 0,43 & 1,00 \\
\hline III.20 & 0,210 & 0,90 & 0,91 \\
\hline III.30 & 0,380 & 0,27 & 0,74 \\
\hline IV.10 & 0,516 & 0,16 & 0,66 \\
\hline IV. 20 & 0,099 & 2,63 & 0,89 \\
\hline IV.30 & 0,686 & 0,27 & 0,56 \\
\hline V.10 & 0,530 & 0,00 & 0,71 \\
\hline V.20 & 0,468 & 0,19 & 0,57 \\
\hline V.30 & 0,480 & 0,08 & 0,71 \\
\hline VI.10 & 0,599 & 0,00 & 0,74 \\
\hline VI.20 & 0,405 & 0,14 & 0,53 \\
\hline VI.30 & 0,548 & 0,03 & 0,51 \\
\hline
\end{tabular}




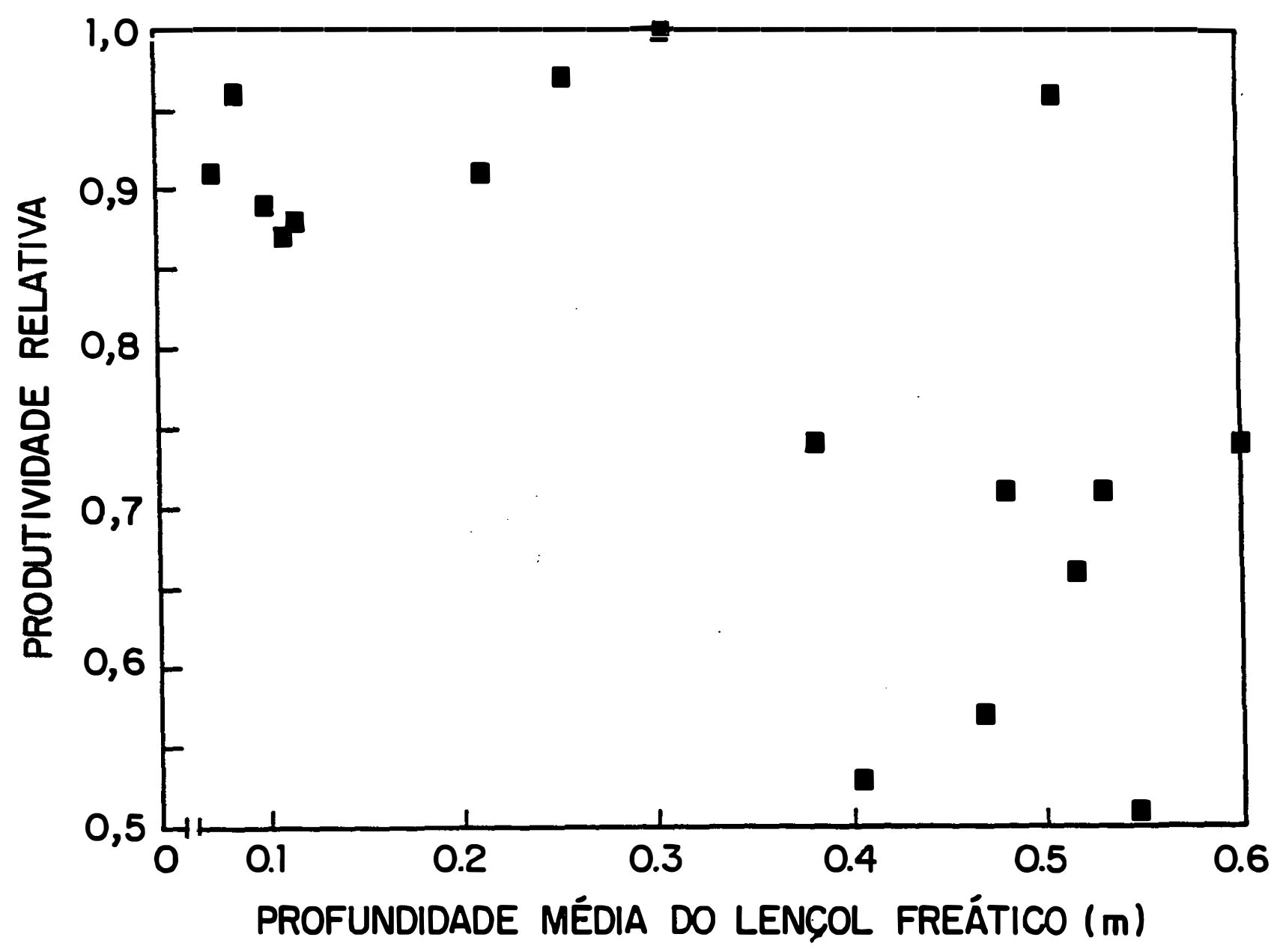

Figura 8 - Dispersão de pontos entre produtividade relativa e profundidade média do lençol freático 


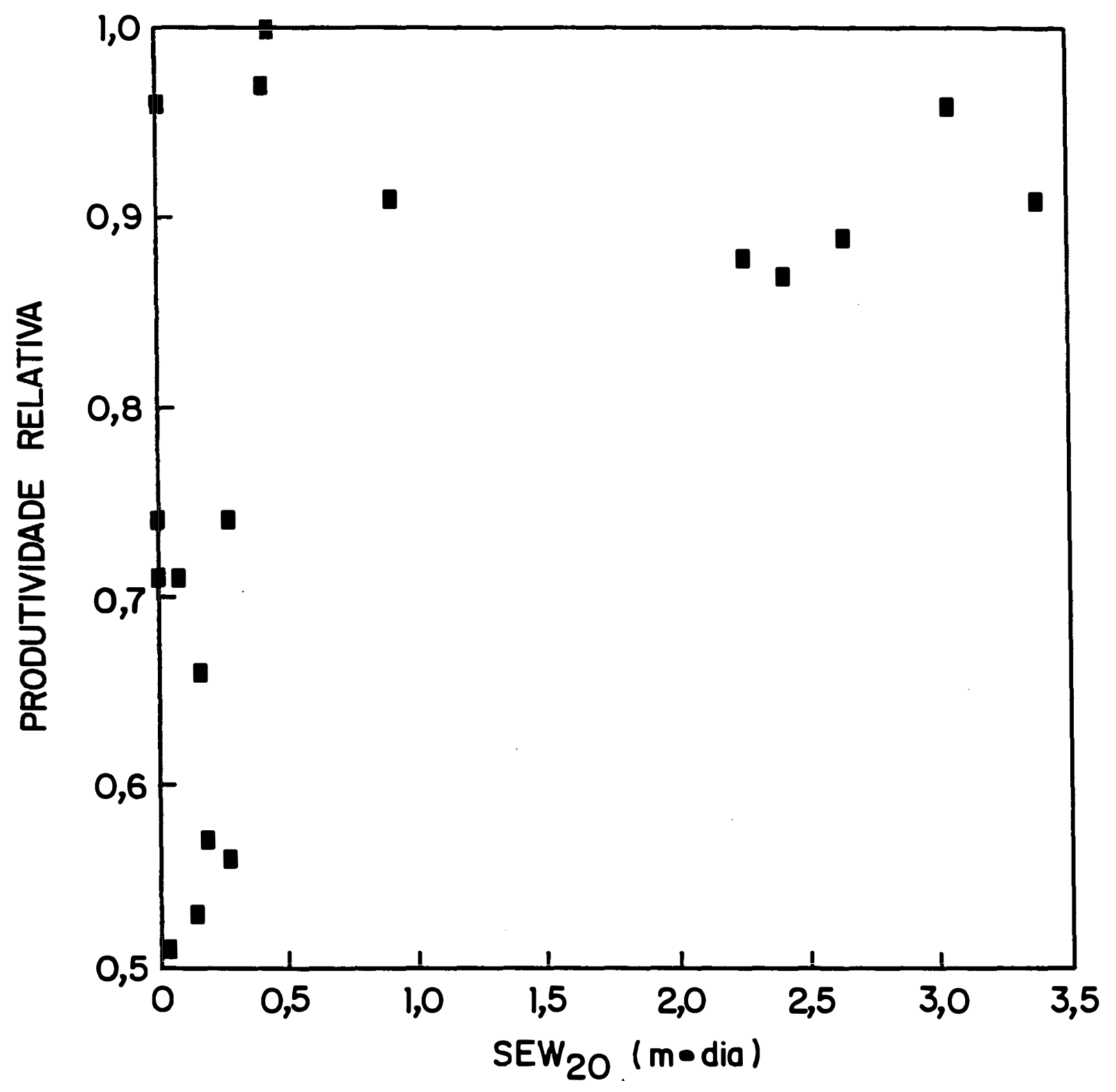

Figura 9 - Dispersão de pontos observados entre produtividade relativa e $\mathrm{SEW}_{20}$ 
Quadro 13. Análises de regressão da produtividade relativa em função da profundidade média do lençol freático

\begin{tabular}{llcc}
\hline Modelo & Equação & $r$ & $r^{2}$ \\
Linear & $\hat{Y}=0,9843-0,5721 X$ & $-0,70$ & 0,49 \\
Exponencial & $\hat{\mathrm{Y}}=1,0037 . \mathrm{e}^{-0,7713 \mathrm{X}}$ & $-0,69$ & 0,48 \\
Potencial & $\hat{\mathrm{Y}}=0,6018 \cdot \mathrm{X}^{-0,1885}$ & $-0,64$ & 0,41
\end{tabular}

$\hat{Y}:$ profundidade relativa;

$\mathrm{X}$ : profundidade média do lençol freático.

Análise estatística do modelo $\hat{\mathrm{Y}}=0.9843-0.5721 \mathrm{X}$

\begin{tabular}{lcccc}
\hline F.V. & G.L. & S.Q. & Q.M. & F \\
\hline Regressão & 1 & 0,2262 & 0,2262 & $14,9327^{*}$ \\
Resíduo & 16 & 0,2423 & 0,0151 & \\
\hline Total & 17 & 0,4685 & & \\
\hline
\end{tabular}

* Significativo pelo teste $\mathrm{F}$ ao nível de 5\%

Análise estatística do modelo $\hat{Y}=1,0037 . e^{-0,7713 X}$

\begin{tabular}{lcccc}
\hline F.V. & G.L. & S.Q. & Q.M. & F \\
\hline Regressão & 1 & 0,4111 & 0,4111 & $14,3745^{*}$ \\
Resíduo & 16 & 0,4576 & 0,0286 & \\
\hline Total & 17 & 0,8687 & & \\
\hline
\end{tabular}

* Significativo pelo teste $\mathrm{F}$ ao nível de 5\%

Análise estatística do modelo $\hat{\mathrm{Y}}=0,6018 \cdot \mathrm{X}^{-0,1885}$

\begin{tabular}{lcccc}
\hline F.V. & G.L. & S.Q. & Q.M. & F \\
\hline Regressão & 1 & 0,0673 & 0,0673 & $11,1620^{*}$ \\
Resíduo & 16 & 0,0965 & 0,0060 & \\
\hline Total & 17 & 0,1638 & & \\
\hline
\end{tabular}

* Significativo pelo teste $\mathrm{F}$ ao nível de 5\% 
Quadro 14. Análises de regressão da produtividade relativa em função do fator de estresse $\left(\mathrm{SEW}_{20}\right)$

$\begin{array}{llll}\text { Modelo } & \text { Equação } & \mathbf{r} & \mathbf{r}^{2} \\ \text { Linear } & \hat{Y}=0,7150+0,0731 X & 0,53 & 0,28 \\ \text { Exponencial } & \hat{Y}=0,6975 . e^{0,0996} & 0,53 & 0,28 \\ \text { Potencial } & \hat{Y}=0,8307 . X^{0,1246} & 0,77 & 0,59\end{array}$

$\hat{\mathrm{Y}}$ : profundidade relativa;

$\mathrm{X}$ : profundidade média do lençol freático.

Análise estatística do modelo $\hat{\mathrm{Y}}=0.9843-0.5721 \mathrm{X}$

\begin{tabular}{lcclc}
\hline F.V. & G.L. & S.Q. & Q.M. & F \\
\hline Regressão & 1 & 0,1306 & 0,1306 & $6,1808^{*}$ \\
Resíduo & 16 & 0,3380 & 0,0211 & \\
\hline Total & 17 & 0,4686 & & \\
\hline
\end{tabular}

* Significativo pelo teste $\mathrm{F}$ ao nível de $5 \%$

Análise estatística do modelo $\hat{\mathrm{Y}}=0,6975 \cdot \mathrm{e}^{0,0996 x}$

\begin{tabular}{lcclc}
\hline F.V. & G.L. & S.Q. & Q.M. & F \\
\hline Regressão & 1 & 0,2421 & 0,2421 & $6,1823^{*}$ \\
Resíduo & 16 & 0,6266 & 0,0392 & \\
\hline Total & 17 & 0,8687 & & \\
\hline
\end{tabular}

* Significativo pelo teste $\mathrm{F}$ ao nível de $5 \%$

Análise estatística do modelo $\hat{Y}=0,8307 \cdot X^{0,1246}$

\begin{tabular}{lcccc}
\hline F.V. & G.L. & S.Q. & Q.M. & F \\
\hline Regressão & 1 & 0,0897 & 0,0897 & $18,5262^{*}$ \\
Resíduo & 13 & 0,0629 & 0,0048 & \\
\hline Total & 17 & 0,1526 & & \\
\hline
\end{tabular}

* Significativo pelo teste F ao nível de 5\% 
As análises de variância mostram que todos os modelos foram significativos pelo teste $\mathrm{F}$ ao nível de $5 \%$, indicando assim uma rejeição da hipótese de nulidade. A hipótese alternativa diz que existe a regressão, embora o ajuste, com base nos respectivos coeficientes de determinação $\left(\mathrm{r}^{2}\right)$, tenham apresentado valores relativamente baixos.

KANWAR et al. (1988), pesquisando sobre os efeitos do excesso de água no solo em vários estádios de desenvolvimento da cultura de milho, verificaram, durante três anos consecutivos, que o modelo linear apresentou o melhor ajuste ao se analisarem as relações entre produtividade relativa e $\mathrm{SEW}_{30}$. Determinaram, também, modelos quadráticos no estudo das relações entre produtividade relativa e profundidade média do lençol freático. HARDJOAMIDJOJO et al. (1982) determinaram um modelo linear como o de melhor ajuste, nas relações entre produtividade relativa e estresse diário.

O resultado da análise de regressão, para os dados de produtividade relativa em função de $\mathrm{SEW}_{20}$, de fato sugere que a produtividade do milho pode aumentar com os valores de $\mathrm{SEW}_{20}$, o que constitui, à primeira vista, um resultado contrário ao esperado. Resultado semelhante ao da pesquisa foi encontrado por KANWAR et al. (1988).

$\mathrm{Na}$ verdade, a presente análise indicou que o rendimento da cultura não foi comprometido por excesso de umidade nos estádios analisados, devendo isso estar associado à variedade de milho estudada, que revelou possuir um sistema radicular muito superficial. 
Embora a área tenha recebido recargas intensas, durante o período correspondente às análises em questão, o desempenho hidráulico do sistema de drenagem foi capaz de promover, em tempo hábil, uma depleção nos níveis freáticos, de sorte a não comprometer o rendimento da cultura.

Com um lençol freático em declínio, que pode retratar as condições de cultivo observadas em um lisímetro de drenagem com carga variável, ou mesmo a época de cultivo no período não chuvoso para regiões com estações bem definidas, é de se esperar um aumento no rendimento da cultura à medida que esse lençol se aprofunde. Essa correlação positiva ocorreria até um determinado limite de profundidade, onde a cultura apresentaria um máximo rendimento, sendo esse primeiro estádio caracterizado pelo efeito da drenagem, que propiciaria melhores condições de aeração na zona radicular da cultura. A continuidade de descida do lençol freático, entretanto, criaria uma correlação negativa entre as variáveis em análise, sendo tal estádio caracterizado por uma condição de déficit de água, tendo em vista que a taxa de contribuição do lençol freático, no processo de evapotranspiração, teria uma redução ao passar do tempo. KANWAR et al. (1988), trabalhando com a cultura de milho com lençol em declínio, estudou faixas de profundidades onde analisou o lado ascendente da curva de resposta.

$\mathrm{Na}$ presente pesquisa, os resultados sugerem que a análise da variável profundidade média do lençol freático sobre o rendimento da cultura não foi totalmente consistente, tendo em vista a mesma não ter representado fielmente as posições e durações das oscilações do lençol freático, elementos de suma importância na suscetibilidade da cultura, e, portanto, no seu rendimento. 


\subsection{Avaliação hidráulica do sistema de drenagem subtemânea}

O funcionamento do sistema de drenagem subterrânea, avaliado através de parâmetros tais como perfis do lençol freático antes e durante a depleção, rede de fluxo e eficiência de rebaixamento do lençol freático, constituem elementos importantes, vindo, por conseguinte, a conferir maior credibilidade na recomendação de resultados da presente pesquisa.

\subsubsection{Perfis do lençol freático}

Foi possível registrar o comportamento do lençol freático a partir de dados coletados junto aos poços de observação, estrategicamente implantados na área. Nesse sentido, traçaram-se perfis do lençol freático para dois blocos de drenos laterais, sendo cada bloco constituído por três drenos consecutivos. Os perfis foram plotados ao final de uma recarga de $64,8 \mathrm{~mm}$, distribuída ao longo de cinco dias, e com o lençol em depleção, 48h após cessada a recarga, conforme mostra a Figura 10(a,b). Considerando uma recarga uniformemente distribuída na área experimental, os perfis mostram a importância da variável espaçamento, expressa através de suas respectivas cargas hidráulicas, após a recarga e depleção do lençol freático. Os drenos laterais, com espaçamento consecutivo de 10,0m, foram capazes de não deixar o lençol freático subir à altura máxima permissível, o que pode ser verificado por suas respectivas cargas hidráulicas. Já os drenos com espaçamento consecutivo de $20,0 \mathrm{~m}$, embora tenham apresentado, em função do tempo, uma magnitude de depleção menor - se comparados aos espaçados de 10,0m - foram capazes de atender aos requisitos pré-estabelecidos. 

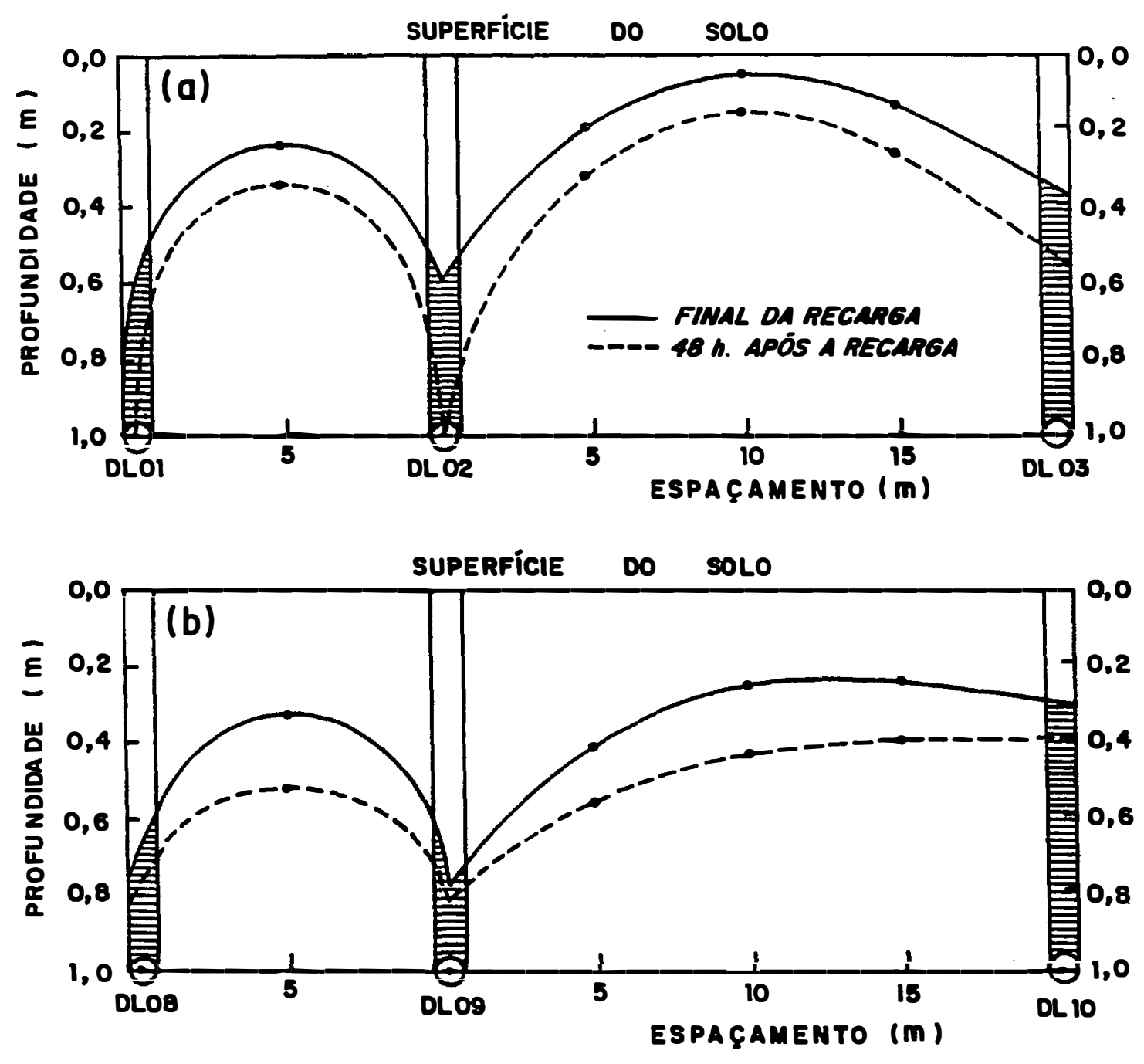

Figura 10 - Perfis do lençol freático durante o processo de drenragem 


\subsubsection{Descrição da rede de fluxo}

A caracterização do comportamento do lençol freático, através da planta de suas curvas de nível, constitui investigação básica para orientar a instalação de um sistema de drenagem subterrânea. $\mathrm{Na}$ presente pesquisa, tal investigação funciona como parâmetro determinante das condições de funcionamento dos drenos laterais.

De acordo com CRUCIANI \& GODOY (1980), metodologias que caracterizem o comportamento do lençol freático são as únicas que apresentam eficiência em estudos para áreas com problemas de drenagem.

COSTA (1988) avaliou sistema de drenagem constituído de manilhas de barro, com base em mapas de isohypsas e critério agronômico. SOUZA (1991) detectou, através de estudos de avaliação, erros no dimensionamento e na instalação, além de ausência de manutenção em sistema de drenagem constituído por tubos de PVC liso e parede delgada, no Perímetro de Maniçoba-Ba.

De posse dos dados de profundidade do lençol freático e do nivelamento geométrico da área experimental, calcularam-se as cotas do lençol freático para cada poço de observação. Em seguida, plotou-se a posição dos poços em um mapa planimétrico. Interpolando-se as cotas do lençol, confeccionou-se a planta de suas curvas de nível para o dia 15.01.1993, com equidistância vertical entre as curvas de 0,10m, conforme mostra a Figura 11.

A direção do fluxo subterrâneo mostra, com clareza, uma descarga no sentido dos drenos laterais, pelas linhas de fluxo aproximadamente ortogonais às linhas equipotenciais, supondo o solo aproximadamente isotrópico, evidenciando, portanto, um funcionamento adequado dos respectivos drenos laterais. 


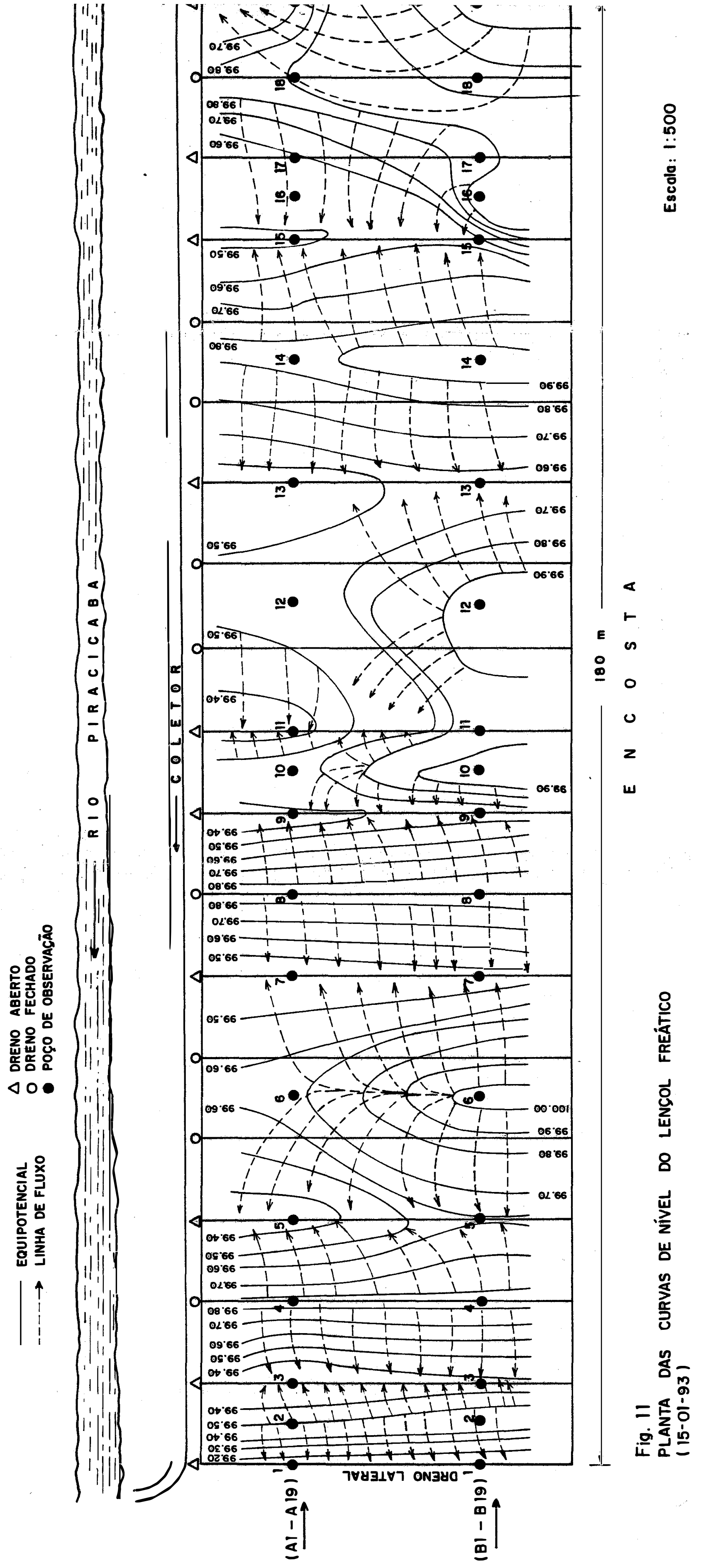




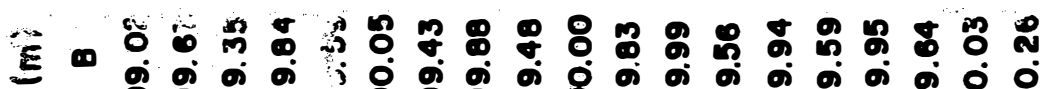

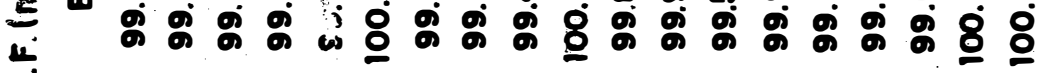

8 范

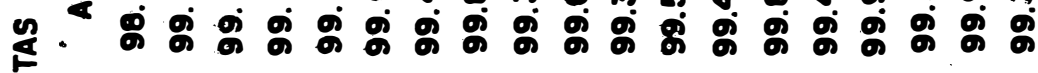

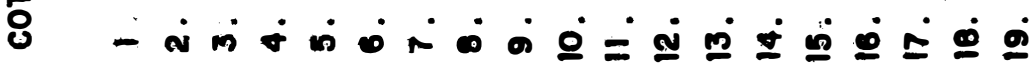

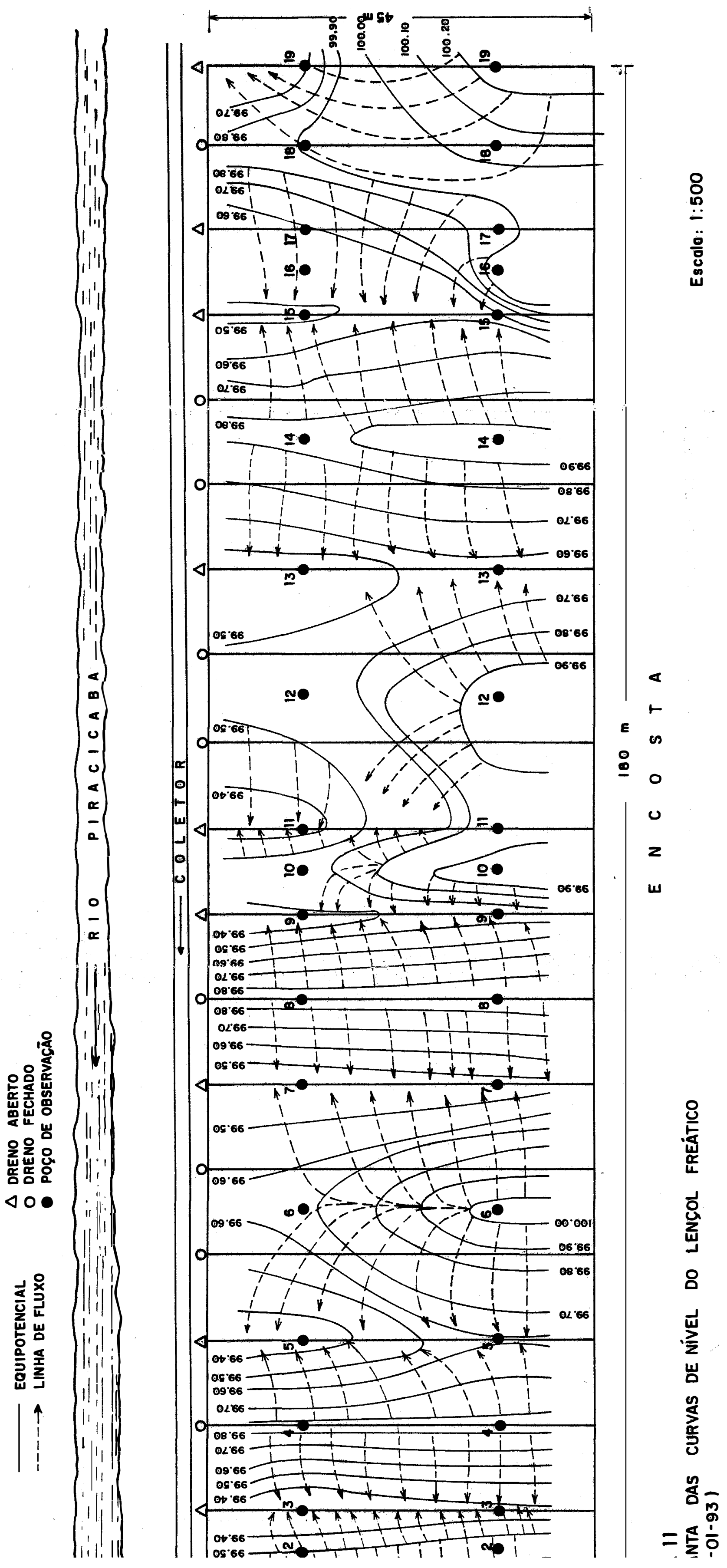




\subsubsection{Eficiência de rebaixamento do lençol freático}

A eficiência de rebaixamento do lençol freático(Er) foi estimada com base na eventualidade de precipitações de elevada intensidade, que, ocasionalmente, poderia elevar o lençol freático próximo à superfície do solo. Essa estimativa representa a capacidade de descarga do dreno, em relação a um coeficiente de drenagem desejado.

No cálculo da eficiência, utilizou-se a seguinte equação:

$$
E_{I}=\left(\frac{\vec{q}}{L d}\right) .100 \ldots . . . . .
$$

sendo:

$\overrightarrow{\mathrm{q}}$ - densidade de fluxo, $L \cdot \mathrm{T}^{-1}$;

Ld- coeficiente de drenagem, $L . T^{-1}$;

A densidade de fluxo foi calculada pela relação entre a descarga do dreno e sua respectiva área de domínio, sendo, em seguida, convertida para m. $\mathrm{s}^{-1}$. Utilizaram-se dados disponíveis de descargas dos drenos laterais intermediários de $\mathrm{n}^{\mathrm{os}} 04$, 07 e 09, escolhidos aleatoriamente.

O tempo de drenagem deverá ser função da cultura e de seu estádio vegetativo, tendo em vista os diferentes graus de suscetibilidade da cultura. CRUCIANI (1981) sugere que o tempo de drenagem da zona radicular da cultura de milho deva ser inferior a três dias.

$\mathrm{Na}$ estimativa do coeficiente de drenagem, considerou-se uma depleção do lençol freático $(\Delta \mathrm{h})$ de $0,2 \mathrm{~m}$ após $48 \mathrm{~h}$, significando que, caso ocorresse uma 
recarga que o levasse à condição mais crítica, ele iria à profundidade mínima desejável após dois dias.

Dessa forma, o coeficiente de drenagem foi estimado de acordo com a seguinte equação:

$$
L d=\frac{\Delta h . \alpha}{t} \cdot . . . . . . . .
$$

sendo:

$$
\begin{aligned}
& \Delta h \text { - depleção do lençol freático, } L ; \\
& t \text { - tempo de drenagem, } T \\
& \alpha \text { - porosidade drenável, adimensional. }
\end{aligned}
$$

Com base no coeficiente de drenagem para as condições acima referidas, da ordem de $8,68 \times 10^{-8} \mathrm{~m} \cdot \mathrm{s}^{-1}$, a eficiência foi calculada por ocasião do término de duas recargas distintas, referentes aos períodos de 23 a 27.01 .1993 com recarga de $37,8 \mathrm{~mm}$ e 07 a 11.02 .1993 com recarga de $64,8 \mathrm{~mm}$. Apresentaram os valores médios de 81,6\%, $86,6 \%$ e $66,2 \%$, respectivamente, para os drenos laterais de n's 04,07 e 09.

A disparidade no valor encontrado para o dreno lateral $\mathrm{n}^{\circ} 09$, em relação aos demais, pode ser atribuída à sua localização próxima à extremidade da área, lado oposto ao ponto de deságue. Os resultados de eficiência de rebaixamento do lençol freático podem ser considerados satisfatórios, tendo em vista a depleção do lençol freático ter ocorrido em tempo hábil. 


\section{CONSIDERAÇÕES GERAIS:}

Tendo em vista algumas limitações encontradas no trabalho, e a continuidade da presente linha de pesquisa, tem-se a considerar:

- A variedade de milho Piranão VD2, cujo porte do sistema radicular se revelou muito superficial, embora tenha se constituido em carácter indesejável no presente trabalho, demonstra ser vantajosa e recomendada para o cultivo em áreas com problemas de drenagem. Para isso, um sistema de drenagem superficial bem dimensionado é fundamental;

- As pequenas dimensões da área dificultaram a adequacidade do delineamento experimental, bem como a utilização de maiores espaçamentos como alternativas de análise;

- Sugere-se a utilização da metodologia do SEW, em conjunto com o fator de suscetibilidade da cultura, com análise individual para cada estádio do ciclo vegetativo. 


\section{CONCLUSÕES}

Em face dos resultados obtidos para as condições do experimento e tendo em vista o porte do sistema radicular da cultura, além do dimensionamento econômico visando a maximização da renda líquida sem a minimização dos custos, o presente trabalho permitiu as seguintes conclusões:

- O espaçamento entre drenos laterais de $30,0 \mathrm{~m}$ foi a melhor alternativa econômica, por apresentar maior valor de renda líquida anual. Verificou-se, também, a relevância dos custos fixos na análise de tomada de decisão;

- O resultado da análise do índice de estresse $\mathrm{SEW}_{20}$, indicou que o rendimento da cultura não foi comprometido por excesso de umidade nos estádios analisados, devendo isso estar associado à variedade de milho estudada, que revelou possuir um sistema radicular muito superficial; 
- Não foi totalmente consistente a análise do rendimento da cultura em função da profundidade média do lençol freático, por não ter esta representado fielmente as posições e durações das oscilações do lençol freático;

- As cargas hidráulicas sobre os drenos, $48 \mathrm{~h}$ após a recarga do lençol freático, mostraram que os mesmos foram capazes de satisfazer ao coeficiente de drenagem adotado (rebaixamento do lençol freático em $0,2 \mathrm{~m}$ após 2 dias). Ao mesmo tempo, a direção do fluxo subterrâneo, no sentido dos drenos laterais, evidenciou uma locação e, portanto, um funcionamento adequado dos mesmos. 


\section{REFERÊNCIAS BIBLIOGRÁFICAS}

AHMAD, N.; KANWAR, R. S.; KASPAR, T. C.; BAILEY, T. B. Effect of soil surface submergence and a water table on vegetative growth and nutrient uptake of com. Transactions of the ASAE, St. Joseph, 35(4): 1173 - 7, 1992.

ALVINO, A. \& ZERBI, G. Water-table level effect on the yield of irrigated and unirrigated grain maize. Transactions of the ASAE, St. Joseph, 29(4): 1086 - 9, 1986.

ANDRADE, L. M. Efeito de diferentes profundidades freáticas sobre a evapotranspiração e sobre a produção e os componentes da produção do milho-doce (Zea mays, L.). Viçosa, 1991. 53p. (Mestrado - Universidade Federal de Viçosa).

ANDRADE, L. M. \& REIS, A. E. G. Efeito da profundidade do lençol freático nas culturas de soja, de milho e de arroz. Pesquisa Agropecuária Brasileira, Brasília, 27(6): 923-33, 1992.

BENZ, L. C.; DOERING, E. J.; REICHMAN, G. A. Water table and irrigation effects on alfalfa grown on sandy soils. Canadian Agricultural Engineering, Ottawa, 24(2): 71 $5,1982$.

BENZ, L. C.; REICHMAN, G. A.; DOERING, E. J.; FOLLETT, R. F. Water table depth and irrigation effects on applied-water-use efficiencies of three crops. Transactions of the ASAE, St. Joseph, 21: 723 - 8, 1978. 
BOUWER, H. Developing drainage design criteria. In: VAN SCHILFGAARDE, J., ed. Drainage for agriculture. Madison, American Society of Agronomy, 1974. p. 67 - 79. (Monographs, 17).

BOUYOUCOS, G. J. Estimation of the coloidal material in soils. Science, Washington, 64: 362, 1926.

CARTER, C. C.; HALVERSON, B.; ROGERS, J. S.; MUSGRAVE, M. Effects of excess soil water on sweet corn yield. Transactions of the ASAE, St. Joseph, 33(4): 1203 7, 1990.

CERVELLINI, A.; SALATI, E.; BARROS FERRAZ, E. S.; VILLA NOVA, N. A.; REICHARDT, K.; DECICO, A.; OMETTO, J. C.; PEDRO JÚNIOR, M. J. Análise dos dados meteorológicos de Piracicaba. Piracicaba, ESALQ, 1973. 26p. (Boletim Científico, 36).

CHAUDHARY, T. N.; BHATNAGAR, V. K.; PHINAR, S. S. Corn yield and nutrient uptake as affected by water table depth and soil submergence. Agronomy Joumal, Madison, 67: 745 - 9, 1975.

COOPER, R. L.; FAUSEY, N. R.; STREETER, J. G. Yield potential of soybean grown under a subirrigation/drainage water manegement system. Agronomy Joumal, Madison, 83: 884 - 7, 1991.

COSTA, R. N. T. Avaliação de um sistema de drenagem e tratamentos mecânicos na recuperação de um solo sódico no Vale do Curu-Ce. Fortaleza, 1988. 75p. (Mestrado - Universidade Federal do Ceará).

CRUCIANI, D. E. Caracterização de coeficientes de drenagem com base nos parâmetros de produção das culturas. Piracicaba, 1981. 99p. (Livre-Docência - Escola Superior de Agricultura "Luiz de Queiroz"/USP). 
CRUCIANI, D. E. A drenagem na agricultura. 4.ed. São Paulo, Nobel, 1989, 337p.

CRUCIANI, D. E. \& GODOY, R. Estudos do lençol freático em problemas de drenagem. Revista de Agricultura, 115 - 126, 1980.

CURI, N.; RESENDE, M.; SANTANA, O. P. Solos de várzea de Minas Gerais. In: Informe Agropecuário, Belo Horizonte, 13(152): p. 3 - 9, 1986.

EVANS, R. O.; SKAGGS, R. W.; SNEED, R. E. Normalized crop susceptibility factors for corn and soybean to excess water stress. Transactions of the ASAE, St. Joseph, 33(4): 1153 - 61, 1990.

FANCELLI, A. L. \& LIMA, U. A. Milho: produção, pré- processamento e transformação agroindustrial. São Paulo, Sec. Ind. Com. Cienc. Tec. s.d. 112p. (Extensão Agroindustrial, 5), 1982.

FAO, Drainage design factors; 28 questions and answers. Rome, FAO, 1986. 52p. (FAO. Irrigation and Drainage Paper, 38).

FAUSEY, N. R.; VAN-TOAI, T. T.; McDONALD, M. B. Response of ten corn cultivars to flooding. Transactions of the ASAE, St. Joseph, 28(6): 1794 - 7, 1985.

FOLLETT, R. F.; ALLMARAS, R. R.; REICHMAN, G. A. Distribution of corn roots in sandy soil with a declining water table. Agronomy Joumal, Madison, 66: 288 - 92, 1974.

FOLLETT, R. F.; DOERING, E. J.; REICHMAN, G. A.; BENZ, L.C. Effect of irrrigation and water-table depth on crop yields. Agronomy Joumal, Madison, 66: 304 - 8, 1974.

GOINS, T.; LUNIN, J.; WORLEY, H. L. Water table effects on growth of tomatoes, snap beans and sweet corn. Transactions of the ASAE, St. Joseph, 9: 530 - 3, 1966. 
GOMES, F. P. Curso de estatística expenimental. 13. ed. São Paulo, Nobel, 1990. 468p.

HARDJOAMIDJOJO, S.; SKAGGS, R. W.; SCHWAB, G. O. Corn yield response to excessive soil water conditions. Transactions of the ASAE, St. Joseph, 25(4): 922 7, 34, 1982.

HILER, E. A. Quantitative evaluation of crop-drainage requirements. Transactions of the ASAE, St. Joseph, 12(4): 499 - 505, 1969.

HILER, E. A. \& CLARK, R. N. Stress day index to characterize effects of water stress on crop yields. Transactions of the ASAE, St. Joseph, 14(4): 757 - 61, 1971.

HILER, E. A.; CLARK, R. N.; GLASS, L. J. Effects of water table height on soil aeration and crop response. Transactions of the ASAE, St. Joseph, 14: 879 - 82, 1971.

HOFFMANN, R.; ENGLER, J. J. C.; SERRANO, O.; THAME, A.C.M.; NEVES, E. M. Administração da empresa agrícola 7. ed. São Paulo, Pioneira, 1992. 325p.

HOWELL, T. A. \& HILER, E. A. Effects of inundation period on seedling growth. Transactions of the ASAE, St. Joseph, 17: 286 - 8, 94, 1974.

HOWELL, T. A.; HILER, E. A.; ZOLEZZI, O.; RAVELO, C. Grain sorghum response to inundation at three growth stages. Transactions of the ASAE, St. Joseph, 19: 876 - 80, 1976.

JOSHI, M. S. \& DASTANE, N. G. Studies in excess water tolerance of crop plants: II. Effect of different durations of flooding at different stages of growth under different layouts on growth, yield and quality of maize. Indian Joumal of Agronomy, New Delhi, 11(1): 70 - 9, 1966.

KALITA, P. K. \& KANWAR, R. S. Shallow water table effects on photosynthesis and corn yield. Transactions of the ASAE, St. Joseph, 35(1): 97 - 104, 1992. 
KANDIL, H. M. \& WILLARDSON, L. S. Relating crop-yield response to water-table fluctuations. Joumal of Imigation and Drainage Engineering, New York, 118(1): 113 21, 1992.

KANWAR, R. S.; BAKER, J. L.; MUKHTAR, S. Excessive soil water effects at various stages of development on the growth and yield of corn. Transactions of the ASAE, St. Joseph, 31(1): $133-41,1988$

KRAMER, P. J. Plant and soil water relationships: a modern syntesis. New York, McGrawHill, 1969. 482p.

LAL, R. \& TAYLOR, G. S. Drainage and nutrient effects in a field lisymeter study: I. Corn yield and soil conditions. Soil Science Society of America Procedings, Madison, 33: 937 - 41, 1969.

LAMSTER, E. C. Programa nacional de aproveitamento racional de várzeas - PROVÁRZEAS nacional. Informe Agropecuánio, Belo Horizonte, 6(65): 3 - 8, 1980.

LIMA, C. A. S.; FERREIRA, P. A.; CAIXETA, T. J.; LOUREIRO, B.T. Efeito de seis profundidades do lençol freático sobre o comportamento da cultura do feijão (Phaseolus vulgaris, L.). Revista Ceres, Viçosa, 33(186): 99 - 107, 1986.

MARQUES JÚNIOR, S.; PAZ, V. P. S.; COSTA, R. N. T.; FRIZZONE, J. A. Modelo computacional para estimativa das precipitações mensais prováveis utilizando a distribuição gama incompleta. Revista Engenharia Rural, Piracicaba, 5(1): 20 - 33, 1994.

MELLO, N. T. C. de; CEZAR, S. A. G.; REIS FILHO, J. G. dos; CHABARIBERY, D.; OKAWA, H. Estimativas de custo operacional de produção das principais atividades agropecuárias do Estado de São Paulo. Informações Economicas, São Paulo, 16(7): 25-110, jul. 1986. 
MUKHTAR, S.; BAKER, J. L.; KANWAR, R. S. Corn growth as affected by excess soil water. Transactions of the ASAE, St. Joseph, 32(2): 437 - 42, 1990.

PATERNIANI, E. Origem e comportamento do milho piranão. Piracicaba, ESALQ/Dept ${ }^{\circ}$ Genética, 1973. 217p. (Relatório Científico, 7).

PATWARDHAN, A. S.; NIEBER, J. L.; MOORE, I. D. Oxygen, carbon dioxide, and water transfer in soils: mechanisms and crop response. Transactions of the ASAE, St. Joseph, 31(5): 1383 - 95, 1988.

PEREIRA, A. R. \& ARRUDA, H. V. Ajuste prático de cuvas na pesquisa biológica. Campinas, Fundação Cargill, 1987. 50p.

PEREIRA, R. S. B. Caracteres correlacionados com a produção e suas altrações no melhoramento genético do milho (Zea mays, L.). Piracicaba, 1990. 99p. (Mestrado Escola Superior de Agricultura "Luiz de Queiroz"/USP).

PINTO, J. M. Efeito de diferentes regimes hídricos no solo sobre a produção e os componentes da produção do feijoeiro (Phaseolus vulgaris, L.). Viçosa, 1985. 56p. (Mestrado - Universidade Federal de Viçosa).

PIZARRO, F. Drenaje agnícola y recuperacion de suelos salinos. Madrid, Editorial Agrícola Epañola, 1978, 521p.

PREÇOS AGRÍCOLAS, Piracicaba (98): 35, 1994.

REICOSKY, D. C.; CAMPBELL, R. B.; DOTY, C. W. Corn plant water stress as influenced by chiseling, irrigation, and water-table depth. Agronomy Joumal, Madison, 68: 499 - 503, 1976.

RITTER, W. F. \& BEER, C. E. Yield reduction by controlled flooding of corn. Transactions of the ASAE, St. Joseph, 12: 46 - 50, 1969. 
SCHILFGAARDE, J. V. \& WILLIAMSON, R. E. Studies of crop response to drainage: I. Growth Chambers. Transactions of the ASAE, St. Joseph, 8: 94 - 7, 1965.

SINGH, R. \& GHILDYAL, B. P. Soil submergence effects on nutrient uptake, growth and yield of five corn cultivars. Agronomy Joumal, St. Joseph, 72: 737 - 41, 1980.

SOUZA, J. B. Avaliação e eficiência do sistema de drenos subsuperficiais e tratamentos mecânicos na melhoria das condições de drenabilidade dos solos do Perímetro Maniçoba-Ba. Fortaleza, 1991. 112. (Mestrado - Universidade Federal do Ceará).

SUDAR, R. A.; SAXTON, K. E.; SPOMER, R. G. A predictive model of water stress in com and soybeans. St. Joseph, 1979. 19p. (ASAE Paper, 79-2004).

TOVEY, R. Alfalfa growth as influenced by static and fluctuating water tables. Transactions of the ASAE, St. Joseph, 7: 310 - 2, 1964.

WESSELING, J. Crop growth and wet soils. In: VAN SCHILFGAARDE, J. Drainage for agriculture. Madison, American Society of Agronomy, 1974. cap.2, p. 7 - 37.

WILLIAMSON, R. E. The effect of root aeration on plant growth. Soil Science Society of America Procedings, Madison, 28: 86 - 90, 1964.

WILLIAMSON, R. E. \& KRIZ, G. J. Response of agricultural crops to flooding, depth of water table and gaseous composition. Transactions of the ASAE, St. Joseph, 13(1): $216-20,1970$.

WILLIAMSON, R. E. \& SCHILFGARDE, J. V. Studies of crop response to drainage: II. Lysimeters. Transactions of the ASAE, St. Joseph, 8: 98 - 102, 1965.

WILLIAMSON, R. E.; WILLEY, C. R.; GRAY, T. N. Effect of water-table depth and flooding on yield of millet. Agronomy Joumal, Madison, 61: 310 - 3, 1969. 
ZOLEZZI, O.; HOWELL, T. A.; RAVELO, C. J.; HILER, E. A. Grain sorghum response to inundation at the early reproductive growth stage. Transactions of the ASAE, St. Joseph, 21: 687 - 90, 1978. 


\section{A P Ê N D I C E}


Quadro 1. Precipitação pluvial(mm) no ciclo da cultura

\begin{tabular}{|c|c|c|c|c|c|}
\hline Data & Prec. & Data & Prec. & Data & Prec. \\
\hline 06.11 .92 & 0,9 & 21.12 .92 & 0,0 & 04.02 .93 & 5,7 \\
\hline 07.11 & 0,0 & 22.12 & 0,0 & 05.02 & 2,3 \\
\hline 08.11 & 7,4 & 23.12 & 0,0 & 06.02 & 0,6 \\
\hline 09.11 & 0,2 & 24.12 & 0,0 & 07.02 & 4,5 \\
\hline 10.11 & 0,0 & 25.12 & 0,0 & 08.02 & 5,9 \\
\hline 11.11 & 0,0 & 26.12 & 2,9 & 09.02 & 4,4 \\
\hline 12.11 & 12,2 & 27.12 & 0,0 & 10.02 & 12,8 \\
\hline 13.11 & 0,0 & 28.12 & 0,0 & 11.02 & 37,2 \\
\hline 14.11 & 0,0 & 29.12 & 0,0 & 12.02 & 0,5 \\
\hline 15.11 & 0,0 & 30.12 & 0,0 & 13.02 & 0,0 \\
\hline 16.11 & 12,7 & 31.12 & 0,0 & 14.02 & 30,0 \\
\hline 17.11 & 0,0 & 01.01 .93 & 0,0 & 15.02 & 19,9 \\
\hline 18.11 & 0,0 & 02.01 & 2,3 & 16.02 & 21,3 \\
\hline 19.11 & 0,0 & 03.01 & 3,4 & 17.02 & 5,0 \\
\hline 20.11 & 0,0 & 04.01 & 0,3 & 18.02 & 0,0 \\
\hline 21.11 & 0,5 & 05.01 & 1,1 & 19.02 & 24,4 \\
\hline 22.11 & 3,5 & 06.01 & 3,2 & 20.02 & 8,2 \\
\hline 23.11 & 2,6 & 07.01 & 0,9 & 21.02 & 0,3 \\
\hline 24.11 & 87,8 & 08.01 & 7,8 & 22.02 & 20,1 \\
\hline 25.11 & 17,1 & 09.01 & 11,0 & 23.02 & 3,3 \\
\hline 26.11 & 2,5 & 10.01 & 23,3 & 24.02 & 0,0 \\
\hline 27.11 & 0,0 & 11.01 & 28,4 & 25.02 & 0,0 \\
\hline 28.11 & 0,0 & 12.01 & 39,4 & 26.02 & 0,0 \\
\hline 29.11 & 0,0 & 13.01 & 0,2 & 27.02 & 3,5 \\
\hline 30.11 & 6,0 & 14.01 & 2,6 & 28.02 & 0,0 \\
\hline 01.12 & 32,4 & 15.01 & 0,0 & 01.03 & 0,0 \\
\hline 02.12 & 0,0 & 16.01 & 0,0 & 02.03 & 0,0 \\
\hline 03.12 & 0,0 & 17.01 & 0,0 & 03.03 & 0,0 \\
\hline 04.12 & 0,0 & 18.01 & 2,0 & 04.03 & 0,0 \\
\hline 05.12 & 0,0 & 19.01 & 1,2 & 05.03 & 0,0 \\
\hline 06.12 & 7,0 & 20.01 & 5,9 & 06.03 & 0,0 \\
\hline 07.12 & 0,0 & 21.01 & 0,0 & 07.03 & 0,0 \\
\hline 08.12 & 0,0 & 22.01 & 0,0 & 08.03 & 0,0 \\
\hline 09.12 & 7,2 & 23.01 & 5,4 & 09.03 & 0,0 \\
\hline 10.12 & 66,2 & 24.01 & 4,5 & 10.03 & 0,0 \\
\hline 11.12 & 8,9 & 25.01 & 19,3 & 11.03 & 0,0 \\
\hline 12.12 & 0,0 & 26.01 & 7,1 & 12.03 & 0,0 \\
\hline 13.12 & 0,0 & 27.01 & 1,5 & 13.03 & 0,0 \\
\hline 14.12 & 0,0 & 28.01 & 0,0 & 14.03 & 0,0 \\
\hline 15.12 & 0,0 & 29.01 & 0,0 & 15.03 & 0,0 \\
\hline 16.12 & 0,0 & 30.01 & 0,0 & 16.03 & 2,9 \\
\hline 17.12 & 12,5 & 31.01 & 9,1 & 17.03 & 0,0 \\
\hline 18.12 & 5,1 & 01.02 & 0,0 & 18.03 & 2,4 \\
\hline 19.12 & 0,0 & 02.02 & 9,5 & 19.03 & 34,4 \\
\hline 20.12 & 0,0 & 03.02 & 12,7 & & \\
\hline
\end{tabular}


Quadro 2. Descarga dos drenos laterais( $1 / \mathrm{s})$

\begin{tabular}{|c|c|c|c|c|c|}
\hline Data & DL.01 & DL.02 & DL.03 & DL.04 & DL.05 \\
\hline $\begin{array}{l}15.01 \\
18.01 \\
19.01 \\
20.01 \\
21.01 \\
22.01 \\
26.01 \\
27.01 \\
29.01 \\
31.01 \\
01.02 \\
03.02 \\
04.02 \\
08.02 \\
09.02 \\
11.02 \\
12.02 \\
14.02 \\
19.02 \\
24.02 \\
27.02\end{array}$ & $\begin{array}{l}0,025 \\
0,020 \\
0,020 \\
0,020 \\
0,022 \\
0,021 \\
0,110 \\
0,090 \\
0,026 \\
0,021 \\
0,030 \\
0,045 \\
0,089 \\
0,035 \\
0,032 \\
0,058 \\
0,900 \\
0,050 \\
\text { afogado } \\
0,360 \\
0,093\end{array}$ & $\begin{array}{l}0,060 \\
0,037 \\
0,032 \\
0,030 \\
0,035 \\
0,030 \\
0,120 \\
0,093 \\
0,036 \\
0,029 \\
0,046 \\
0,056 \\
0,079 \\
0,044 \\
0,043 \\
0,059 \\
0,190 \\
0,054 \\
0,084 \\
0,110 \\
0,083\end{array}$ & $\begin{array}{l}0,065 \\
0,055 \\
0,055 \\
0,055 \\
0,055 \\
0,055 \\
0,080 \\
0,080 \\
0,055 \\
0,045 \\
0,052 \\
0,061 \\
0,069 \\
0,057 \\
0,056 \\
0,070 \\
0,100 \\
0,063 \\
0,097 \\
0,120 \\
0,110\end{array}$ & $\begin{array}{l}0,075 \\
0,070 \\
0,060 \\
0,060 \\
0,060 \\
0,060 \\
0,085 \\
0,090 \\
0,060 \\
0,055 \\
0,057 \\
0,065 \\
0,075 \\
0,059 \\
0,058 \\
0,075 \\
0,105 \\
0,064 \\
0,096 \\
0,130 \\
0,100\end{array}$ & $\begin{array}{l}0,070 \\
0,025 \\
0,025 \\
0,025 \\
0,025 \\
0,025 \\
0,045 \\
0,045 \\
0,022 \\
0,021 \\
0,025 \\
0,030 \\
0,037 \\
0,036 \\
0,028 \\
0,039 \\
0,067 \\
0,030 \\
0,051 \\
0,100 \\
0,055\end{array}$ \\
\hline Data & DL.06 & DL.07 & DL.08 & DL.09 & DL. 10 \\
\hline $\begin{array}{l}15.01 \\
18.01 \\
19.01 \\
20.01 \\
21.01 \\
22.01 \\
26.01 \\
27.01 \\
29.01 \\
31.01 \\
01.02 \\
03.02 \\
04.02 \\
08.02 \\
09.02 \\
11.02 \\
12.02 \\
14.02 \\
19.02 \\
24.02 \\
27.02\end{array}$ & $\begin{array}{l}0,045 \\
0,035 \\
0,035 \\
0,035 \\
0,035 \\
0,035 \\
0,055 \\
0,055 \\
0,031 \\
0,029 \\
0,030 \\
0,038 \\
0,047 \\
0,027 \\
0,026 \\
0,045 \\
0,105 \\
0,039 \\
0,100 \\
\text { afogado } \\
\text { afogado }\end{array}$ & $\begin{array}{l}0,095 \\
0,075 \\
0,075 \\
0,070 \\
0,071 \\
0,070 \\
0,100 \\
0,100 \\
0,075 \\
0,069 \\
0,067 \\
0,073 \\
0,090 \\
0,065 \\
0,067 \\
0,083 \\
0,150 \\
0,081 \\
0,136 \\
0,190 \\
0,155\end{array}$ & $\begin{array}{l}0,035 \\
0,025 \\
0,025 \\
0,025 \\
0,025 \\
0,025 \\
0,035 \\
0,036 \\
0,024 \\
0,021 \\
0,020 \\
0,024 \\
0,040 \\
0,020 \\
0,022 \\
0,034 \\
0,100 \\
0,035 \\
0,065 \\
0,110 \\
0,080\end{array}$ & $\begin{array}{l}0,045 \\
0,029 \\
0,025 \\
0,020 \\
0,020 \\
0,020 \\
0,045 \\
0,047 \\
0,020 \\
0,016 \\
0,013 \\
0,017 \\
0,052 \\
0,018 \\
0,018 \\
0,044 \\
0,146 \\
0,037 \\
0,092 \\
0,160 \\
0,100\end{array}$ & $\begin{array}{l}0,045 \\
0,020 \\
0,015 \\
0,015 \\
0,015 \\
0,015 \\
0,030 \\
0,039 \\
0,012 \\
0,010 \\
0,008 \\
0,011 \\
0,029 \\
0,013 \\
0,013 \\
0,032 \\
0,130 \\
0,034 \\
0,110 \\
0,160 \\
0,130\end{array}$ \\
\hline
\end{tabular}


Quadro 3. Leitura de poços de observação - Data: 15.01 .93

\begin{tabular}{|c|c|c|c|c|c|c|}
\hline \multicolumn{3}{|c|}{ Cotas dos poços $(m) L$} & \multicolumn{3}{|c|}{ Dados calculados(m) } & \multirow[b]{2}{*}{ CHPMD } \\
\hline $\mathbf{N}^{\circ}$ & Sup. & Topo & Topo poço & Cota LF & PLFNS & \\
\hline $\mathrm{A} 01$ & 99,84 & 100,14 & 1,20 & 98,94 & 0,90 & \\
\hline A02 & 99,84 & 100,14 & 0,62 & 99,52 & 0,32 & 0,68 \\
\hline $\mathrm{A} 03$ & 99,79 & 100,09 & 0,88 & 99,21 & 0,58 & \\
\hline A04 & 99,90 & 100,20 & 0,38 & 99,82 & 0,08 & 0,92 \\
\hline A05 & 99,80 & 100,10 & 0,77 & 99,33 & 0,47 & \\
\hline A06 & 99,94 & 100,24 & 0,56 & 99,68 & 0,26 & 0,74 \\
\hline A07 & 100,00 & 100,30 & 0,90 & 99,40 & 0,60 & \\
\hline A08 & 99,94 & 100,24 & 0,38 & 99,86 & 0,08 & 0,92 \\
\hline A09 & 99,98 & 100,28 & 0,93 & 99,34 & 0,63 & \\
\hline A10 & 100,05 & 100,35 & 0,70 & 99,65 & 0,40 & 0,60 \\
\hline A11 & 100,03 & 100,33 & 0,99 & 99,34 & 0,69 & \\
\hline A12 & 100,12 & 100,42 & 0,85 & 99,57 & 0,55 & 0,45 \\
\hline A13 & 100,29 & 100,59 & 1,15 & 99,44 & 0,85 & \\
\hline A14 & 100,42 & 100,72 & 0,86 & 99,86 & 0,56 & 0,44 \\
\hline A15 & 100,28 & 100,58 & 1,10 & 99,48 & 0,80 & \\
\hline A16 & 100,37 & 100,67 & 0,77 & 99,90 & 0,47 & 0,53 \\
\hline A17 & 100,33 & 100,63 & 1,07 & 99,56 & 0,77 & \\
\hline A18 & 100,32 & 100,62 & 0,70 & 99,92 & 0,40 & 0,60 \\
\hline A19 & 100,20 & 100,50 & 0,78 & 99,72 & 0,48 & \\
\hline B01 & 99,69 & 99,99 & 0,97 & 99,02 & 0,67 & \\
\hline B02 & 99,73 & 100,03 & 0,36 & 99,67 & 0,06 & 0,94 \\
\hline B03 & 99,71 & 100,01 & 0,66 & 99,35 & 0,36 & \\
\hline B04 & 99,89 & 100,19 & 0,35 & 99,84 & 0,05 & 0,95 \\
\hline B05 & 99,98 & 100,28 & 0,68 & 99,59 & 0,38 & \\
\hline B06 & 100,08 & 100,38 & 0,33 & 100,05 & 0,03 & 0,97 \\
\hline B07 & 100,09 & 100,39 & 0,96 & 99,43 & 0,66 & \\
\hline B08 & 100,13 & 100,43 & 0,55 & 99,88 & 0,25 & 0,75 \\
\hline B09 & 100,19 & 100,49 & 1,01 & 99,48 & 0,71 & \\
\hline B10 & 100,31 & 100,61 & 0,61 & 100,00 & 0,31 & 0,69 \\
\hline B11 & 100,38 & 100,68 & 0,85 & 99,83 & 0,55 & \\
\hline B12 & 100,38 & 100,68 & 0,69 & 99,99 & 0,39 & 0,61 \\
\hline B13 & 100,42 & 100,72 & 1,16 & 99,56 & 0,86 & \\
\hline B14 & 100,44 & 100,74 & 0,80 & 99,94 & 0,50 & 0,50 \\
\hline B15 & 100,45 & 100,75 & 1,15 & 99,59 & 0,85 & \\
\hline B16 & 100,45 & 100,75 & 0,79 & 99,95 & 0,49 & 0,51 \\
\hline B17 & 100,44 & 100,74 & 0,90 & 99,84 & 0,60 & \\
\hline B18 & 100,49 & 100,79 & 0,76 & 100,03 & 0,46 & 0,54 \\
\hline B19 & 100,50 & 100,80 & 0,54 & 100,26 & 0,24 & \\
\hline
\end{tabular}

PLFNS: profundidade do lençol freático ao nível do solo CHPMD: carga hidráulica no ponto médio entre drenos 
Quadro 4. Profundidades do lençol freático(m)

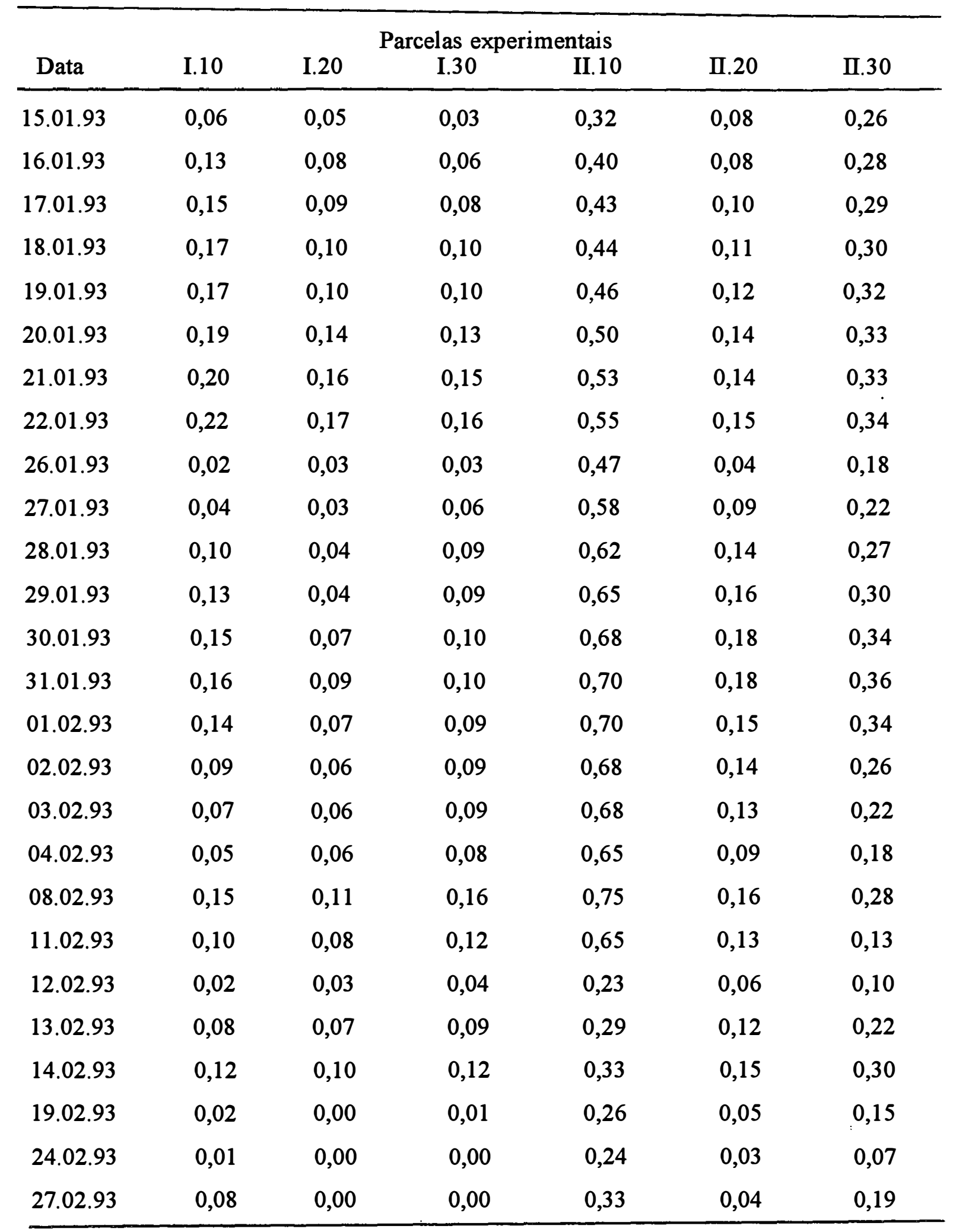


Quadro 4 - continuação.

\begin{tabular}{|c|c|c|c|c|c|c|}
\hline \multirow[b]{2}{*}{ Data } & \multirow[b]{2}{*}{ III. 10} & \multirow[b]{2}{*}{ III. 20} & \multicolumn{2}{|c|}{ Parcelas experimentais } & \multirow[b]{2}{*}{ IV.20 } & \multirow[b]{2}{*}{ IV.30 } \\
\hline & & & III.30 & IV.10 & & \\
\hline 15.01 .93 & 0,31 & 0,25 & 0,39 & 0,40 & 0,08 & 0,55 \\
\hline 16.01 .93 & 0,33 & 0,27 & 0,42 & 0,47 & 0,10 & 0,65 \\
\hline 17.01 .93 & 0,34 & 0,28 & 0,44 & 0,49 & 0,12 & 0,68 \\
\hline 18.01 .93 & 0,35 & 0,28 & 0,45 & 0,52 & 0,13 & 0,70 \\
\hline 19.01 .93 & 0,36 & 0,28 & 0,46 & 0,56 & 0,14 & 0,74 \\
\hline 20.01 .93 & 0,38 & 0,29 & 0,47 & 0,61 & 0,14 & 0,77 \\
\hline 21.01 .93 & 0,39 & 0,29 & 0,47 & 0,64 & 0,14 & 0,78 \\
\hline 22.01 .93 & 0,39 & 0,30 & 0,49 & 0,64 & 0,15 & 0,80 \\
\hline 26.01 .93 & 0,20 & 0,12 & 0,32 & 0,61 & 0,02 & 0,78 \\
\hline 27.01 .93 & 0,22 & 0,13 & 0,36 & 0,65 & 0,06 & 0,89 \\
\hline 28.01 .93 & 0,31 & 0,22 & 0,42 & 0,66 & 0,08 & 0,91 \\
\hline 29.01 .93 & 0,37 & 0,27 & 0,45 & 0,67 & 0,09 & 0,91 \\
\hline 30.01 .93 & 0,39 & 0,29 & 0,47 & 0,68 & 0,12 & 0,93 \\
\hline 31.01 .93 & 0,40 & 0,29 & 0,49 & 0,68 & 0,14 & 0,94 \\
\hline 01.02 .93 & 0,38 & 0,27 & 0,47 & 0,68 & 0,11 & 0,93 \\
\hline 02.02 .93 & 0,35 & 0,24 & 0,44 & 0,67 & 0,08 & 0,92 \\
\hline 03.02 .93 & 0,34 & 0,23 & 0,42 & 0,67 & 0,06 & 0,92 \\
\hline 04.02 .93 & 0,30 & 0,14 & 0,32 & 0,57 & 0,05 & 0,87 \\
\hline 08.02 .93 & 0,40 & 0,26 & 0,48 & 0,54 & 0,15 & 0,88 \\
\hline 11.02 .93 & 0,33 & 0,19 & 0,36 & 0,51 & 0,06 & 0,55 \\
\hline 12.02 .93 & 0,25 & 0,07 & 0,22 & 0,13 & 0,05 & 0,34 \\
\hline 13.02 .93 & 0,31 & 0,17 & 0,34 & 0,27 & 0,11 & 0,46 \\
\hline 14.02 .93 & 0,33 & 0,24 & 0,41 & 0,36 & 0,14 & 0,53 \\
\hline 19.02 .93 & 0,12 & 0,04 & 0,19 & 0,26 & 0,10 & 0,11 \\
\hline 24.02 .93 & 0,02 & 0,02 & 0,02 & 0,11 & 0,05 & 0,02 \\
\hline 27.02 .93 & 0,03 & 0,02 & 0,12 & 0,37 & 0,10 & 0,28 \\
\hline
\end{tabular}


Quadro 4 - continuação.

\begin{tabular}{|c|c|c|c|c|c|c|}
\hline \multirow[b]{2}{*}{ Data } & \multirow[b]{2}{*}{ V.10 } & \multicolumn{3}{|c|}{ Parcelas experimentais } & \multirow[b]{2}{*}{ VI.20 } & \multirow[b]{2}{*}{ VI.30 } \\
\hline & & V.20 & V.30 & VI.10 & & \\
\hline 15.01 .93 & 0,49 & 0,46 & 0,50 & 0,47 & 0,40 & 0,56 \\
\hline 16.01 .93 & 0,51 & 0,50 & 0,53 & 0,51 & 0,43 & 0,59 \\
\hline 17.01 .93 & 0,52 & 0,52 & 0,54 & 0,53 & 0,44 & 0,60 \\
\hline 18.01 .93 & 0,52 & 0,54 & 0,55 & 0,55 & 0,45 & 0,61 \\
\hline 19.01 .93 & 0,56 & 0,58 & 0,55 & 0,55 & 0,45 & 0,63 \\
\hline 20.01 .93 & 0,58 & 0,57 & 0,57 & 0,60 & 0,47 & 0,64 \\
\hline 21.01 .93 & 0,58 & 0,58 & 0,57 & 0,63 & 0,48 & 0,64 \\
\hline 22.01 .93 & 0,60 & 0,58 & 0,58 & 0,65 & 0,48 & 0,64 \\
\hline 26.01 .93 & 0,52 & 0,33 & 0,40 & 0,62 & 0,36 & 0,51 \\
\hline 27.01 .93 & 0,53 & 0,39 & 0,47 & 0,74 & 0,37 & 0,54 \\
\hline 28.01 .93 & 0,56 & 0,47 & 0,51 & 0,75 & 0,43 & 0,58 \\
\hline 29.01 .93 & 0,58 & 0,52 & 0,54 & 0,75 & 0,47 & 0,60 \\
\hline 30.01 .93 & 0,61 & 0,56 & 0,56 & 0,76 & 0,50 & 0,63 \\
\hline 31.01 .93 & 0,63 & 0,58 & 0,57 & 0,76 & 0,51 & 0,64 \\
\hline 01.02 .93 & 0,63 & 0,58 & 0,56 & 0,74 & 0,50 & 0,62 \\
\hline 02.02 .93 & 0,60 & 0,56 & 0,51 & 0,72 & 0,47 & 0,61 \\
\hline 03.02 .93 & 0,59 & 0,56 & 0,48 & 0,72 & 0,46 & 0,60 \\
\hline 04.02 .93 & 0,56 & 0,54 & 0,46 & 0,70 & 0,37 & 0,47 \\
\hline 08.02 .93 & 0,62 & 0,61 & 0,58 & 0,79 & 0,50 & 0,63 \\
\hline 11.02 .93 & 0,57 & 0,45 & 0,53 & 0,60 & 0,38 & 0,56 \\
\hline 12.02 .93 & 0,43 & 0,14 & 0,33 & 0,32 & 0,25 & 0,25 \\
\hline 13.02 .93 & 0,49 & 0,36 & 0,44 & 0,45 & 0,35 & 0,44 \\
\hline 14.02 .93 & 0,54 & 0,54 & 0,50 & 0,52 & 0,43 & 0,56 \\
\hline 19.02 .93 & 0,37 & 0,29 & 0,31 & 0,41 & 0,28 & 0,50 \\
\hline 24.02 .93 & 0,27 & 0,07 & 0,12 & 0,23 & 0,06 & 0,17 \\
\hline 27.02 .93 & 0,33 & 0,30 & 0,22 & 0,51 & 0,23 & 0,44 \\
\hline
\end{tabular}

